\title{
Coín en época andalusí, centro administrativo y militar de la Algarbía malagueña
}

Coin during the Andalusian period, the administrative and military center of the Algarbía malagueña

\section{Francisco Marmolejo Cantos}

\section{OpenEdition}

\section{Journals}

Edición electrónica

URL: http://journals.openedition.org/medievalista/984

DOI: 10.4000/medievalista.984

ISSN: 1646-740X

Editor

Instituto de Estudos Medievais - FCSH-UNL

\section{Referencia electrónica}

Francisco Marmolejo Cantos, «Coín en época andalusí, centro administrativo y militar de la Algarbía malagueña », Medievalista [En línea], 19 | 2016, Puesto en línea el 01 junio 2016, consultado el 21 abri 2019. URL : http://journals.openedition.org/medievalista/984 ; DOI : 10.4000/medievalista.984

(C) IEM 
Título: Coín en época andalusí, centro administrativo y militar de la Algarbía malagueña | Coín during the Andalusian period, the administrative and military center of the Algarbía malagueña

Autor: Francisco Marmolejo Cantos

Universidade: Universidad de Málaga

Faculdade e Departamento / Unidade de Investigação: Asociación Arqueológica de Coín Código Postal: 29.100

Cidade: Coín (Málaga)

País: Espanha

Contacto: arqueologiacoin@gmail.com

Fonte: Medievalista [Em linha]. Dir. Bernardo Vasconcelos e Sousa. Lisboa: IEM.

Disponível em:

http://www2.fcsh.unl.pt/iem/medievalista/MEDIEVALISTA19/marmolejo1905.html

ISSN: 1646-740X

Data recepção do artigo: 6 de Fevereiro de 2015

Data aceitação do artigo: 27 de Julho de 2015

\section{Resumo}

Nuestra contribución plantea la evolución de un hiṣn andalusí que eventualmente se transforma en madina a medida que se estrecha el cerco a Granada. Se acopia y traduce de los textos andalusíes las diversas noticias que existen dispersas sobre esta población (Dakwān en los textos), la cual centraliza administrativamente el distrito occidental malagueño y preserva su integridad territorial en época nazarí. Recorreremos su historia desde el siglo $\mathrm{X}$ al XV, desde que quedó bajo control de Ibn Hafsūn hasta que fue refortificada como plaza fronteriza por 'Abd al-Raḥmān III y, sin caer en generalidades, seremos testigos excepcionales de cómo la frontera retrocede ante el avance cristiano y la población andalusí se repliega y concentra en el reino de Granada. 
Coín en época andalusí, centro administrativo y militar de la Algarbía malagueña - Francisco Marmolejo Cantos

Palavras-chave: Centro urbano, evolución, Coín, al-Andalus, siglos X-XV.

\section{Abstract}

Our contribution presents the evolution of an Andalusī Castle that eventually becomes a Madina, as Catholic Kings besiege the Granada Kingdom. It collects and translates Andalusī writings over the Malaga town of Coín, which administratively centralized Malaga western sector and preserved its territorial integrity in the Nasrid Period. This paper will trace its history from the 10th to the 15 th century, since it was under the control of 'Umar ibn Hafsun until it was fortified as a frontier town by Abd al-Rahman III. Without falling into generalities, one will witness how the border moves back to the advancing Christian troops and how the Andalusī population retreats and focuses on the Kingdom of Granada.

Keywords: Urban center, evolution, Coin, Al-Andalus, $10^{\text {th }}-15^{\text {th }}$ centuries. 


\title{
son
}

\section{Coín en época andalusí: centro administrativo y militar de la Algarbía malagueña}

\author{
Francisco Marmolejo Cantos
}

\section{Preámbulo}

Desde hace años se viene insistiendo en la necesidad de entrar con más detenimiento en el poblamiento rural alejado de los grandes centros de poder $^{1}$, donde la escasez de monografías impide visionar aspectos fundamentales en la formación, consolidación y decadencia de al-Andalus. Las noticias que nos hacen llegar las fuentes ponderan el grado de integración en el proceso de islamización y castellanización, especialmente en zonas que quedan fuera del control del poder central. Nos dejan una visión inmediata de la organización del territorio y de los factores que inciden en la estructura socioeconómica de estas comunidades. En nuestro ánimo procuramos un acercamiento serio y pormenorizado al mundo rural que supere el alcance de las explicaciones aisladas y superficiales que se vienen dando. En esta línea, el estudio del poblamiento y territorio en nuestro ámbito geográfico presenta un panorama muy sombrío, sin que hasta la fecha haya merecido atención y consideración por parte de la historiografía medieval y moderna ${ }^{2}$.

\footnotetext{
${ }^{1}$ En esta línea consúltese MALPICA CUELLO, Antonio - "Arqueología de los paisajes medievales granadinos: medio físico y territorio en la costa de Granada". in Arqueología y Territorio Medieval 2 (1995), pp. 25-62. BARCELÓ, Miquel - "La arqueología extensiva y el estudio de la creación del espacio rural". in BARCELÓ, Miquel et alii (eds.) - Arqueología medieval. En las afueras del "medievalismo". Barcelona, 1988, pp. 195-274.

${ }^{2}$ Únicamente ha visto la luz el trabajo previo de MARTÍNEZ ENAMORADO, Virgilio - "La Algarabía como realidad geohistórica en el periodo de formación de al-Ándalus. Una aproximación al estudio de su poblamiento rural". in MARTÍN RUIZ, Juan António (ed.) - Arqueología y Patrimonio en la Algarabía
}

Medievalista online № 19| Janeiro - Junho 2016 @ IEM - Instituto de Estudos Medievais 3 
En las estribaciones más meridionales de la gran cordillera Penibética, junto a las sierras litorales del sur peninsular, se alzaba la fortaleza de Coín controlando los pasos de Málaga a Ronda y de Antequera a Marbella, tal se comprueba en el viaje de Ibn Bațțụta o en el trayecto que hizo el sultán Muhammad V cuando tuvo que huir al exilio.

Coín se integró en la circunscripción de Rayya desde época emiral, por entonces con capital en Archidona y posteriormente en Málaga. Las fuentes andalusíes lo dejan claro, no sólo Ibn Hayyān, sino también el Dikr Bilād al-Andalus cuando enumera los nueve castillos y ciudades (posiblemente de mayor importancia) de la cora de Rayya: Marbella, Suhayl, Cártama, Comares, Vélez-Málaga, Dakwān (Coín), Alhama, Antequera y Estepa ${ }^{3}$. Nada dicen los textos andalusíes de manera expresa, pero de dicha enumeración se deduce que Coín debió ser uno de los muchos aqālīm en que estaba divida la circunscripción de Rayya en época altomedieval. Su distrito castral bien pudo extenderse desde río Grande ${ }^{4}$ hasta las sierras litorales limítrofes con Marbella, Mijas y Fuengirola ${ }^{5}$, sobre lo cual tendremos ocasión de ocuparnos. Dentro de su término sólo se detecta la presencia de otra fortaleza de gran entidad, la del cerro de Aljibe o Focairit, con continuidad ocupacional desde época ibérica hasta taifa; sin esquivar el pequeño fortín de Ardite, vigía del paso natural de Río Grande, y las grandes fortalezas de Chilla y de las Cañas, integradas en el dispositivo de control y defensa de la frontera marítima ${ }^{6}$.

Su proximidad a Bobastro favorece que pronto quede bajo control de Ibn Hafsūn, permaneciendo así hasta finales del emirato, cuando en el año 907 los 'rebeldes' pierden la plaza y en 920 se refuerzan sus defensas a iniciativa de 'Abd al-Raḥmān. Dicho esto, se viene insistiendo erróneamente que su castillo es fundación del poder Omeya; cuando la realidad parece bien distinta, pues la batalla que tuvo lugar en el año $907 \mathrm{y}$ sus

malagueña. Málaga, 2003, pp. 57-94; MARMOLEJO CANTOS, Francisco - Históricas y arqueológicas del Medievo en Coín. Málaga, 2009; idem - La Edad Media en Coin y su alfoz. Málaga, 2014.

${ }^{3}$ ANÓNIMO - Dikr Biläd al-Andalus (Una descripción anónima de al Andalus). Edic. y trad. de Luis MOLINA. Madrid, 1983, p. 68 y pp. trad. 73 y 74.

${ }^{4}$ Sobre la identificación de Río Grande con el Guadalquivir malagueño véase GOZALBES CRAVIOTO, Carlos - La fuente y el puente del Rey, Málaga, 1995.

5 Desde hace años venimos insistiendo en esta hipótesis, pese a que todos los autores modernos, con pocas salvedades, contradicen nuestra propuesta al situar erróneamente el castillo de Mawrūr en el cortijo de Morón de Coín. No obstante, desde la primera mitad del siglo XX, figura don Juan Morón Agüera como titular de dicho cortijo, con algo más de 15 Ha. Véase MARMOLEJO CANTOS, Francisco Históricas y arqueológicas del Medievo en Coín. Málaga, 2009; Archivo Histórico Provincial de Málaga (AHPM), Instituto Geográfico y Catastral, catastro histórico de Coín, 1941, polígono 3.

${ }^{6}$ Ibidem.

Medievalista online № 19| Janeiro - Junho 2016 @ IEM - Instituto de Estudos Medievais 4 
consecuencias ponen en evidencia la existencia de un hiṣn fortificado anterior al año 920, probablemente obra impulsada por las estructuras locales o acaso por Ibn Ḥafsūn. Otro dato que no vamos a dejar en el aire es que Dakwān figura acompañado del término Qaštruh en algunos textos ${ }^{7}$, lo que fundamenta su génesis anterior a la arabización lingüística, sin que podamos tampoco caracterizarlo entre los ḥuṣūn-refugio de alta época medieval.

Tras la descomposición del califato cordobés, hiṣn Dakwān continuará bajo dominio de los califas hammūdíes, posiblemente hasta que en 1056 los Banū Zīrí se hicieron con Málaga. Va configurándose como alquería andalusí, ganando espacios de representación tanto del poder militar como religioso, convirtiéndose en el principal conjunto urbano y territorial de la Garbía malagueña. Si bien, los contados datos históricos de los que disponemos inducen a pensar que su fortaleza deja de ser un enclave vital en el panorama político-geográfico de al-Andalus, donde tampoco se ve inmersa en los grandes acontecimientos históricos del momento. Desde el punto de vista arqueológico, los primitivos hușūn-refugio quedaron definitivamente abandonados en el siglo XI, alterándose los distritos castrales en favor de las grandes alquerías fortificadas en cotas inferiores. Esta nueva circunstancia será clave para explicar el posterior desarrollo urbano en el medio rural.

La vida cultural e intelectual alcanza su plenitud en época almohade y representa una de las páginas más bellas de nuestra historia. La actividad científica y literaria como medio de vida no permanece ajena a esta población, en cierta medida vinculada a las producciones de autores como Ibn Kisrà, Šākir, Abū Bakr Ibn Manzūr y posteriormente Aḥmad al-Daqqūn, entre otros sabios ilustres de los que iremos dando cuenta.

En la segunda mitad del siglo XIII su alfoz queda bajo control meriní y pasa a ocupar geográficamente la primera línea de frontera con el reino nazarí de Muhammad II. La producción científica y literaria de Ibn al-Jațīb nos proporciona datos de inestimable valor para el siguiente siglo, ofreciéndonos una visión muy exacta de la entidad geográfica y militar de los distritos occidentales de Ronda y Dakwān en la salvaguardia

\footnotetext{
${ }^{7}$ ARĪB IBN SA 'ĪD - Mujtasar ta'rīj al-Tabarī. in La crónica de Arib sobre al-andalus. Ed. y trad. Juan CASTILLA BRAZALES. Granada, 1992, p. 165. IBN 'IDHĀRİ AL-MARRĀKUŠĪ - al-bayān almugrib fi ajbār al-Andalus wa-l-Magrib. Ed. .G. S. COLIN y Évariste LÉVI-PROVENÇAL. Vol. II. Paris, 1930, p. 180 y trad. de Fagnan, p. 299.
}

Medievalista online № 19| Janeiro - Junho 2016 @ IEM - Instituto de Estudos Medievais 5 
del reino granadino ${ }^{8}$. No de otra suerte, al momento de su conquista, se pudo constatar el papel fundamental que jugaba en la defensa de la ciudad de Málaga.

Es posible fundamentar, pese a estar privados de una lectura arqueológica, que el circuito amurallado debió crearse en momentos tempranos de la baja Edad Media, a la par que su desarrollo urbano; posteriormente se debió acometer el reforzamiento de sus defensas ante el avance cristiano. No obstante, su débil posición geográfica lleva a Ibn al-Jațīb a corroborar que "sus murallas son insuficientes para defenderla", lo que también se puede interpretar en el sentido de que el núcleo poblacional, por entonces, ya se encontraba saturado y había desbordado el perímetro amurallado.

Documentalmente se constata la existencia de una mezquita aljama (antigua iglesia de Santa María) y una mezquita de barrio, situada en la calle Real y cercana a los baños ${ }^{10}$. Igualmente hemos podido detectar la existencia de varias rábitas o zāwiya-s, seguramente de tendencias sufíes y ascéticas en la última etapa andalusí. Una de ellas situada en el ámbito periurbano, conocida como la 'mezquita chiquita'11, con buena parte de sus bienes hábices en la vecina población de Monda, que creemos ubicar bajo los cimientos del antiguo convento Trinitario. Y otra de ellas en la periferia rural, situada en el partido de las Mezquitillas (Carranque) ${ }^{12}$, próxima al despoblado bajomedieval de los Villares de Algane ${ }^{13}$, que quizá nos esté marcando el límite del término de Coín en pleno curso fluvial de Río Grande, habida cuenta de que las tierras de la Jara, ya en la margen opuesta, acabaron anexionadas a esta población con los repartimientos castellanos ${ }^{14}$. Sin entrar en más detalles descriptivos, los límites

\footnotetext{
${ }^{8}$ IBN AL-JAṬĪB - Rayhānat al-kuttāb wa-naŷy'at al-muntāb. Trad. en GASPAR REMIRO, Mariano "Correspondencia diplomática entre Granada y Fez (siglo XIV). Extractos de la 'Reihanat alcuttab' de Lisaneddin Albenajatib El-Andalosi". in Revista del Centro de Estudios Históricos de Granada y su Reino (1916), p. 411.

${ }^{9}$ IBN AL-JAṬīB - Mi 'yār al-ijtiyār fì dirk al-ma 'āhid wa-l-diyār, en Mušāhadāt Lisān al-Dīn b. al- Jaț̄̄b fì bilād al-Magrid wa-l-Andalus (Maymū'a min rasā'ila-hu). Ed. Aḥmad Mujtār al-'Abbādī, Alejandría, 1983, p. 67, trad. Mohammed Kamal Chabana, Marruecos, 1977, p. 138.

${ }^{10}$ Archivo Municipal de Málaga (AMM), Libro de Repartimiento (LR), no IV, fols. $114 \mathrm{v}$ y 165.

${ }^{11} \mathrm{AMM}, \mathrm{LR} \mathrm{n}^{\circ} \mathrm{IV}$, fol. 39v. Véase también del mismo archivo $\mathrm{LR} \mathrm{n}^{\mathrm{O}} \mathrm{V}$, fol. 372v.

${ }^{12}$ Archivo Histórico Provincial de Granada (AHPG), Libro de Poblaciones (LP), $\mathrm{n}^{\circ} 6716$.

${ }^{13}$ GONZÁLEZ MARTíN, Juan - "Aproximación a la investigación arqueológica de los yacimientos medievales del término municipal de Coín". in Guadalhórcete, al Sur de al-Andalus. Málaga, 2007, pp. 179-191. Otras rábitas rurales cercanas, de las cuales daremos cuenta, hemos localizado en Tolox y Yunquera, además de un ribāt en altura en TM de Ojén, controlando la frontera marítima.

${ }^{14}$ Archivo General de Simancas (AGS), Registro General del Sello, Leg.149105, 113. Dicho esto, hemos constatado que todas las alquerías nazaríes situadas en la margen derecha de Río Grande cruzan la orilla opuesta del río, tal es el caso de Guaro, Padules, Casapalma e incluso Coín en algunos sectores.
}

Medievalista online № 19| Janeiro - Junho 2016 ๑ IEM - Instituto de Estudos Medievais 6 
administrativos del Coín nazarí lindaban al Norte con el castillo de Benamaquís y la alquería de Hurique, al Este con el castillo de Fahala y Casapalma, al Oeste con las alquerías de Padules y Pereila y al Norte con el término de la Jara.

De lo que no cabe duda es que los datos históricos y arqueológicos elevan esta población a la categoría de "casi madīna", tal se desprende del Mi y $y \bar{a} r$ de Ibn al-Jațīb ${ }^{15}$ y de la documentación real castellana de los siglo XV y XVI, aunque las fuentes disponibles silencian si dispuso o no de zoco. Esta afirmación, en particular, alcanza todo su significado ante la inexistencia de otros centros urbanos en sus inmediaciones, tal vez como reflejo de su capacidad de aglutinar a la población campesina de su alfoz, atraída sin duda por su gran riqueza agrícola. En esta línea, de ningún modo puede pasar desapercibido cómo Ibn al-Jațîb exalta el carácter residencial de sus (nuevos) edificios, en comparación y semejanza con al-Sadir y al-Jawarnaq, nada menos que las ciudades áulicas más importantes y bellas de oriente.

Habrá que convenir que las transformaciones más notables se dieron en época nazarí; es por entonces cuando desempeña un papel más activo en consonancia con el protagonismo histórico que va adquiriendo en las fuentes andalusíes. No obstante, la expansión demográfica se ha podido constatar en su área de influencia siglos atrás, en época almorávide y almohade, más concretamente en el despoblado de la Torrecilla (siglos XI-XV) y en los Villares del Algane (siglos XII-XV), así como en otras unidades de población de la cuenca de Río Grande, en los términos de Tolox, Alozaina y Guaro. En líneas generales, no queda claro si estos altos niveles demográficos se deben a un proceso de concentración de la población residual dispersa o más bien fue el resultado de un aporte ingente de grupos humanos procedentes del norte de África ${ }^{16}$. De partida, el patrón de asentamiento en los despoblados de su alfoz y en sus alquerías limítrofes se asemeja al descrito para la vega de Granada por A. Malpica Cuello y colaboradores ${ }^{17}$, obligándonos aquí a extrapolar conclusiones por falta de actuaciones arqueológicas.

\footnotetext{
${ }^{15}$ IBN AL-JAṬĪB - Mi 'yār al-ijtiyār ... op. cit., p. 67, trad. p. 138.

${ }^{16}$ MALPICA CUELLO, Antonio - "La expansión de la ciudad de Granada en época almohade. Ensayo de reconstrucción de su configuración". in Miscelánea Medieval Murciana. vol. XXV-XXVI (20012002), pp. 67-116.

${ }^{17}$ MALPICA CUELLO, Antonio - Poblamientos y castillos en Granada. Madrid, 1996; idem - Análisis de los paisajes históricos: de al-Andalus a la sociedad castellana. Salobreña, 2009.
}

Medievalista online № 19| Janeiro - Junho 2016 @ IEM - Instituto de Estudos Medievais 7 
La trama andalusí refleja claramente actividades vinculadas con la vida económica y comercial; con rasgos urbanos y elementos definitorios de lo que debe ser una madina, con representación de autoridades políticas, religiosas y militares, provista de aparato defensivo (alcazaba y murallas), edificios públicos (mezquitas y baños) y sectores industriales y artesanales (molinos, batanes, tenerías, caleras, hornos, ollerías, herrerías, tejares, tiendas y alhóndiga, entre otras muchas instalaciones en sus arrabales). La toponimia menor de los siglos XV-XVI, aplicada a su periferia inmediata, es testimonio más que suficiente del desarrollo económico y urbano que se dio en periodo granadino, más allá de las actividades agrícolas que ponderan Ibn Batțūṭa, Ibn al-Jațīb y el autor del Dikr Bilād al-Andalus.

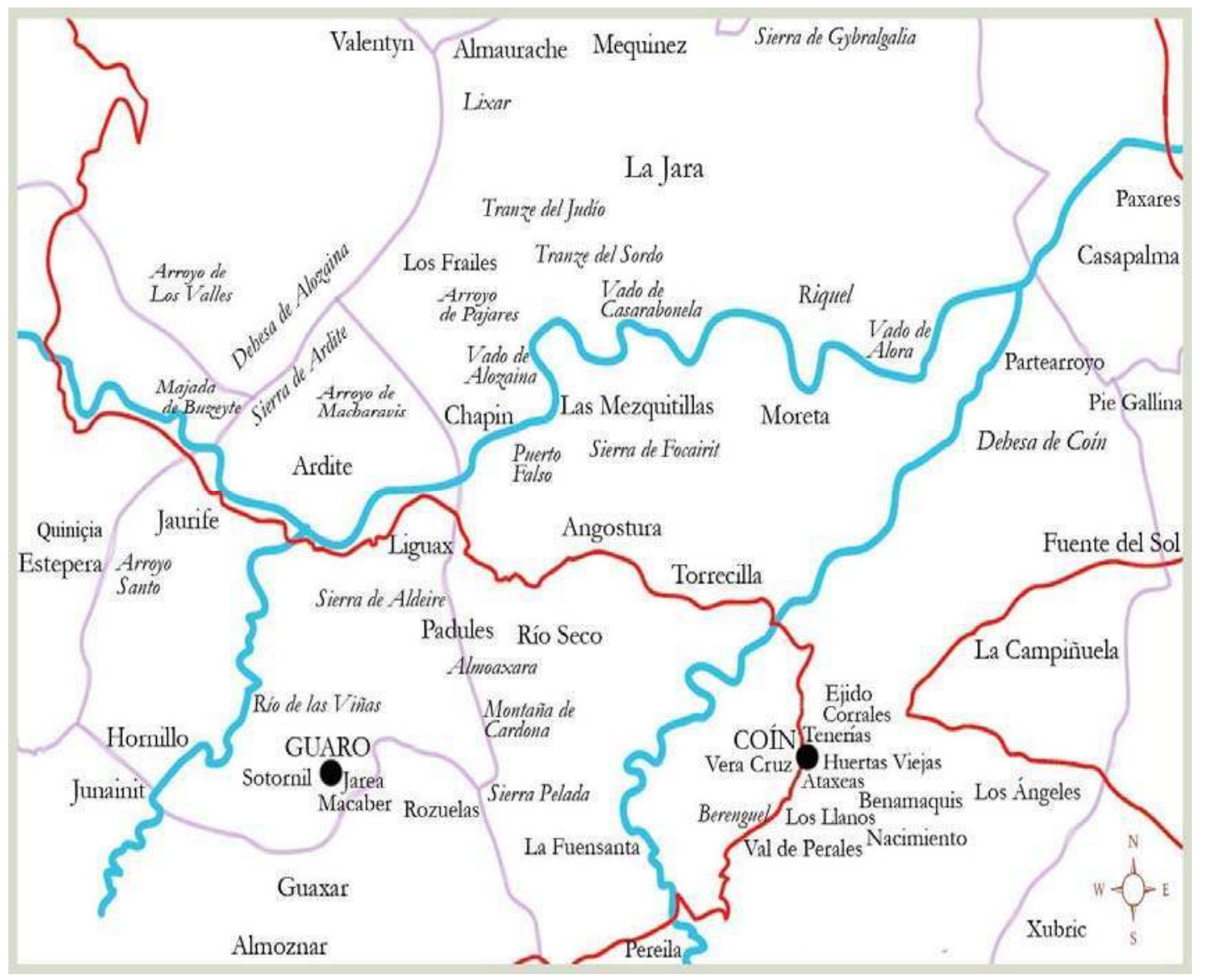

Figura 1. Espacio urbano y rural de Coín. Toponimia de los siglos XV-XVI en la vega de Río Grande. 
Las claves de su desarrollo como ciudad las da Ibn al-Jațīb: "sus edificios son de nueva planta y quienes los habitan y lo que hay dentro de ellas (de sus murallas), carecen de solera" ${ }^{\prime 1}$. De testimonios como éste se deduce las consecuencias inmediatas del avance cristiano y la acogida de la población de frontera, en especial la procedente de las alquerías de la cuenca media del Turón. El profesor M. A. Ladero ha realizado cálculos aproximados para la población nazarí del siglo XV: Vélez Málaga (más de 10.000 habitantes), Ronda (entre 5.000 y 10.000) y Marbella (sobre 3.000 habitantes). Que sepamos el cronista Valera cifra la población de Coín en 3.000 habitantes al momento de su conquista. Por su parte, Alonso de Palencia contabiliza menor número en la batalla; aproximadamente habla "de 1.500 moros" peleando por su castillo, aunque después matiza que "pudieron entrar 400 montañeses muy conocedores de las veredas". Es preciso valorar el crecimiento demográfico de época nazarí en su justa medida, pues obviamente las circunstancias de la conquista justifican las cifras que venimos mostramos. De hecho, al-Maqqarī advierte que había un contingente de los de la Garbía y de Ronda combatiendo en el interior de sus murallas"19.

La documentación castellana no suele tratar a Coín como ciudad en sentido estricto, pese a disponer de caracteres propiamente urbanos; así en los protocolos notariales de los siglos XV y XVI siempre figura como villa y en la erección parroquial de 1505 aparece como un mero locus, aunque se configura como sede vicarial junto al resto de civitates malagueñas. Sólo conocemos una ocasión en la que se le otorga el calificativo de ciudad (ciutat de Cohín): cuando el rey Fernando el Católico comunica a la ciudad de Mallorca la gran victoria conseguida por estas tierras ${ }^{20}$.

\section{Bajo dominio de Ibn Ḥafsūn}

Disponemos de datos suficientes para afirmar, sin temor a equivocarnos, que Dakwān estuvo bajo control de 'Umar ibn Ḥafsūn desde los primeros momentos de la fitna, pese a que sus orígenes permanecen aún inciertos y los testimonios más tempranos se

\footnotetext{
${ }^{18}$ IBN AL-JAṬīB - Mi 'yār al-ijtiyār ... op. cit., p. 67, trad. p. 138.

${ }^{19}$ AL-MAQQAR̄̄ - Nafh al-tīb min gusn al-Andalus al-ratīb. Ed. I. 'Abbās. Beirut, 1968, Vol. IV, p. 515. Véase traducción in VELÁZQUEZ BASANTA, Fernando - "La relación histórica sobre las postrimerías del Reino de Granada, según Aḥmad al-Maqqarī (siglo XVII)". in DEL MORAL, Celia (ed.) - En el epílogo del Islam andalusí. La Granada del siglo XV. Granada, 2002, pp. 514 y 515.

${ }^{20}$ BARCELÓ CRESPÍ, María - "Noticias sobre Málaga del notario mallorquín Pere Llitra". in Actas del VI Coloquio Internacional de Historia Medieval de Andalucía. Málaga, 1991, p. 654.
}

Medievalista online $N^{\circ} 19 \mid$ Janeiro - Junho 2016 @ IEM - Instituto de Estudos Medievais 9 
remontan al siglo X. El Muqtabis III de Ibn Hayyān recoge la primera noticia histórica que se tiene sobre Dakwān ${ }^{21}$ con motivo de una campaña contra Bobastro emprendida por el emir 'Abd Allāh en el año 294/907. Sobre esta expedición decía el profesor Francisco Simonet que, al fin, marchó contra 'Umar ibn Ḥafsūn una hueste cordobesa capitaneada por Abān y Aḥmad. Salieron de Córdoba el primero de mayo, pasando por Tarifa, Algeciras, y otros puntos de aquella costa; después entraron en la circunscripción de Rayya, pasando por Turruš Jušayn, Fuengirola, Coín y Casarabonela, desde donde, atravesando el río llamado Wādì Ban̄̄ 'Abd al-Raḥmān, llegaron sobre Bobastro.

Habrá que convenir que esta campaña se emprendió en el año 294/907, aunque son muchos los arabistas y medievalistas que afirman que tuvo lugar en 284/897. Según Joaquín Vallvé la discordancia en las fechas tiene su explicación si se analiza la cronología, que claramente indica que fue el año 294/22 de octubre de 906-11 de octubre de 907, lo que ocurre es que Ibn Ḥayyān erróneamente la sitúa diez años antes. Más concretamente, la confusión se debe a que en estas dos fechas se llevaron a cabo dos expediciones dirigidas por el infante Abān y que recibieron ambas el mismo nombre: aceifa de Algeciras ${ }^{22}$.

Lo cierto es que la expedición se detuvo en Dakwān para librar batalla, y ésta acabó con derrota de Ibn Ḥafsūn y consecuencias nefastas para la defensa de Bobastro. Cuenta Ibn Hayyān que "el temporal parecía movido por un ejército de demonios. Arrancaba árboles, volaban techos y arrasaba las tiendas clavadas en el campamento. Entonces se tocó a retirada, yéndose el ejército hacia la costa, infiltrándose en las guaridas de los insurrectos, pasando por el alcázar de Marsà al-Šâ̂ara, por el baluarte de al-ŶYanna, Turruš Jušayn, hasta Dakwān, que se hallaba al margen del río. Se acampó en este lugar el día lunes primero de junio - mes cristiano- y se produjo un combate que fue funesto para el ejército del maldito Ibn Hafsūn".

Murieron de los suyos doce oficiales, entre los cuales figuraban dos grandes jefes: Aḥmad Ibn Jayrūn e Ibn al-Aysar y se capturó una tropilla de doce caballos. Desertaron de sus filas doce soldados mercenarios de Tánger, que se pasaron a filas del gobierno.

\footnotetext{
${ }^{21}$ IBN HִAYYĀN - Al-Muqtabis fì ta'rīj rî̀āl al-Andalus. Vol. III, París 1937, p. 121, trad. en GURAIEB, José. E. - ““Al-Muqtabis' de Ibn Ḥayyān”. in Cuadernos de Historia de España. 27-28 (1958), p. 171.

${ }^{22}$ VALLVÉ BERMEJO, Joaquín - "Omar Ben Hafsún, rey de Marmuyas (Comares)". in Boletín de la Real Academia de la Historia. T. 201, cuaderno 2 (2004), pp. 244-246.
}

Medievalista online $N^{\circ} 19 \mid$ Janeiro - Junho 2016 @ IEM - Instituto de Estudos Medievais 10 
Igual derrota sufrió en el castillo de Bunayra (Casarabonela), donde murió un oficial tangerino, huyendo los otros. La deserción en las filas de Ibn Hafsūn iba en aumento, pues de los soldados de Tánger, en esta última refriega, pasaron trece jinetes a las filas del gobierno.

Las tropas omeyas siguen avanzando hasta llegar a Archidona el mismo día de la fiesta de San Juan, el miércoles 24 de junio de 907. La capital de la circunscripción malagueña estaba entonces en poder de 'Umar Ibn Hafsūn y, en nombre de éste, su gobernador entabló negociaciones con el príncipe Abān; tras la entrega de rehenes consiguió la retirada de la fuerzas reales, que llegarán a la capital de Elvira el 1 de julio. El ejército omeya emprende finalmente el regreso a Córdoba el sábado 2 de $d \bar{u} l-q a^{`} d a$ (15 de agosto de 907).

Pedro Chalmeta matiza que, durante esta campaña contra Ibn Ḥafsūn, tras el encuentro de Coín, “doce tangīyūn del rebelde se pasaron al ejército cordobés; luego en Casarabonela cayó un tangerino de los leales, otro morirá después en Archidona, pero desertaron trece" ${ }^{23}$. Será ésta la primera vez que aparezcan reseñados los temidos țangīyūn (tangerinos), uno de los más distinguidos cuerpos de soldados integrados en la estructura militar andalusí.

Indica Chalmeta que a los $a h \grave{s} \bar{a} m$ se les encargará la tenencia y guarnición de las plazas recobradas por el Estado, entre ellas la de Coín. Los denominados aḥ̌sām eran sin embargo los mejores soldados del ejército andalusí, ellos conformaron las tropas profesionales, siempre a disposición permanente, y ventilaron la mayoría de los encuentros contra los rebeldes.

De estos tiempos se conserva hoy en la ciudad de Coín uno de los cenobios rupestres de ámbito periurbano más grandes de la provincia de Málaga ${ }^{24}$; pese a que, en nuestros días, no pasa de ser una serrería para la fabricación de palés de madera, que no logra culminar su declaración como Bien de Interés Cultural.

\section{Fortificación}

${ }^{23}$ CHALMETA GENDRÓN, Pedro - "España Musulmana". in ÁlVAREZ PALENZUELA, Vicente Ángel (coord.) - Historia General de España y América. Vol. III. Madrid, 1988, p. 531.

${ }^{24}$ RÍU I RÍU, Manuel - “Cuevas-eremitorios y centros cenobíticos rupestres en Andalucía Oriental”. in Actas del VIII Congreso Internacional de Arqueología Cristiana. Barcelona, 1972, pp. 439 y ss.

Medievalísta online № 19| Janeiro - Junho 2016 @ IEM - Instituto de Estudos Medievais 11 
Volvemos a encontrar nueva referencia a Dakwān en el año 308/920, dejando entrever su condición de pueblo fortificado y fronterizo. Es el pasaje que más se repite en los textos árabes y tiene su origen en el Mujtasar ta'rīj al-Tabarī escrito por 'Arīb ibn Sa'īd ( siglo X). Lo que se ha venido en llamar la Crónica de 'Arīb dice textualmente:

Este año fue conquistada al-Mundat, situada frente a Cártama, en la cora de Rayya. Fue también construida la fortaleza de Castro Dakwān, a la que (alNasir) dotó de hombres y provisiones ${ }^{25}$.

Esta noticia además de figurar en la Crónica de 'Arīb también es reseñada en el Muqtabis $V$ de Ibn Hayyān y consta también en la Crónica Anónima de 'Abd al-Raḥmān III al-Nasir, pero con un laconismo que la deforma, así como en el Bayān al-mugrib de Ibn 'I

El pasaje escrito por Ibn Hayyān (siglo XI) copia y reproduce íntegramente el texto de 'Arīb, añadiendo cierta referencia a un personaje muy conocido, Ibn Antuluh, acaso obtenida de otro texto de la época. Reseña en su Muqtabis $V$ :

En este año se conquistó al-Maydāt, en el alfoz de Cártama de la Cora de Riyya, construyendo allí el sultán la fortaleza de Dakwān, donde emplazó con mercenarios y pertrechos a Yahyà b. Zakariyyā b. Antuluh ${ }^{27}$.

La Crónica Anónima de 'Abd al-Rahman III al-Nāsir viene a ser un extracto del pasaje que Ibn Ḥayyān toma de 'Arīb. Resulta confusa y divergente de la versión primaria, acaso por una mala interpretación del pasaje que copia del Muqtabis. Dice así: "en este año fortificó Dakwān el castillo de Castro, y metió en él hombres y pertrechos"28.

\footnotetext{
${ }^{25}$ ARĪB IBN SA 'īD - Mujtasar ta'rīj al-Tabarī. in La crónica de Arib sobre al-andalus. Ed. y trad. Juan CASTILLA BRAZALES. Granada, 1992, p. 165.

${ }^{26}$ Añade el profesor Vallvé que el emir 'Abd al-Rahmān III envió a Yahyà ibn Ishāq, señor de Qaštro Dakwān, en el año 308 (23 de mayo de 920 - 11 de mayo de 921) y a Yahyà b. Zakariyyā b. Anatuluh, señor de Casarabonela, en el año 310, para sondear la lealtad de uno de los hijos de Ibn Ḥafsūn. Una Crónica Anónima. pp. 62/132; al-Muqtabas V, pp. 154-155 y nota 3 de esta última página, pp. trad. 124125; al-Bayān. II, pp. 174-175. Véase VALLVÉ BERMEJO, Joaquín - "Omar Ben Hafsún, rey de Marmuyas (Comares)". in Boletín de la Real Academia de la Historia. T. 201, cuaderno 2 (2004), pp. 250,254 y 255.

${ }^{27}$ IBN HAYYĀN - Al-Muqtabas $V$. Ed. P. CHALMETA, F. CORRIENTE y M. SUBH. Madrid, 1979, p. 111, trad. VIGUERA, M ${ }^{a}$ J. y CORRIENTE, F. - Crónica del califa 'Abdarrahman III An-Nasir entre los años 912 y 942. Zaragoza, 1981, p. trad. 134.

${ }^{28}$ ANÓNIMO - Crónica Anónima de 'Abd al-Rahmān III al-Nāsir. Ed. y trad. de E. LÉVI-PROVENÇAL y E. GARCÍA GÓMEZ. Madrid-Granada, 1950, § 38, p. 65 y p. trad. 135.
}

Medievalísta online $\mathrm{N}^{\circ}$ 19| Janeiro - Junho 2016 ๑ IEM - Instituto de Estudos Medievais 12 
La interpolación que existe en esta Crónica Anónima ha llevado a pensar durante años a muchos medievalistas que el topónimo Dakwān tiene su génesis en los Banū Dakwān y que algún miembro de este linaje debió fortificar esta población. Sin negar este posible origen y sin caer en generalidades, la aparición posterior del Muqtabis $V$ ha desvanecido un tanto esta hipótesis, junto a otros trabajos específicos que han tratado y estudiado con rigor la presencia en la península del conocido linaje beréber de los Banū Dakwān ${ }^{29}$. Por lo que sabemos, existe contrariedad en las fuentes árabes sobre sus orígenes: Ibn alFaradī afirma que procedían de la zona de Jaén; Ibn Hayyān dice que eran de los beréberes de Fahs al-Ballüt. En cualquier caso, ninguno de los dos autores ofrece datos concretos sobre la tribu a la que pertenecían. Tampoco existe información sobre el momento en que se produce su paso a al-Andalus desde el Norte de África. Su más antiguo representante documentado es Abū Bakr 'Abd Allāh b. Harțama b. Dakwān, residente en Córdoba durante el siglo X, tuvo tres hijos y falleció en $981^{30}$.

La fuente más tardía que se hace eco del pasaje de 'Arīb es el conocido Bayān almugrib escrito por Ibn 'Iḍhārī (siglos XIII-XIV) que no vamos a reproducir aquí por razones obvias ${ }^{31}$.

\section{3. Época de cambios}

Los textos andalusíes dejan constancia de la actividad intelectual y literaria que irradió desde la pequeña alquería de Coín, en especial desde época almohade. La publicación de la obra histórica de Ibn 'Askar ha permitido conocer unos versos compuestos aquí en el siglo XII por los afamados poetas Ibn Kisrà y Šākir ${ }^{32}$. La escena trascurre a las afueras de Coín, en un río de exiguo caudal con grandes peces, en el que se retrata

\footnotetext{
${ }^{29}$ No quisiera dejar en el aire la evolución del topónimo hasta acabar convertido definitivamente en Coín. La mayor transformación se explica por la inflexión del sonido /ā/ hacia /i/, así Dakwān sería pronunciado Dakwinn, evolucionando finalmente a kwin para acabar en la forma actual Coín.

${ }^{30}$ FELIPE, Helena de - Identidad y onomástica de los beréberes de al-Andalus. Madrid, 1997, pp. 108114.

${ }^{31}$ IBN 'ID̈HĀRĪ AL-MARRĀKUŠİ - al-bayān al-mugrib fì ajbār al-Andalus wa-l-Magrib. vol. II, ed. COLIN y LÉVI-PROVENÇAL, p. 180 y trad. de FAGNAN, p. 299. Dice así: "El-Mondát, qui est [...] de Córdove (sic. por Cártama) et appatient au canton de Málaga, fut conquise. Il construisit le chàteau-fort de Castro Dhakwàn et y installa une garnison et les approvisionnements nécessaires".

${ }^{32}$ IBN 'ASKAR-IBN JAMĪS - al-Ikmāl wa-l-i 'lām fì silat al-i 'lām bì-mahāsin al-a 'lām min ahl Mālaqa al-Kirām. Manuscrito de la Biblioteca General de Rabat, $\mathrm{n}^{\circ}$ 26; ed. SALĀH YARRĀR, Kitāb Udabāa Mālaqa matla 'al-anwār wa-nuzhat al-basā' in wa-l-absār fì-mā ihtawt' alay-hi Mālaqa min al-ā' lām alrū sā' wa-l-ajyār wa-taqiyyid mālaham min al-munāqib wa-l-ātār. Ammán, 1998, p. 353, nº 165.
}

Medievalísta online № 19| Janeiro - Junho 2016 @ IEM - Instituto de Estudos Medievais 13 
naturaleza y paisaje; sin que podamos extraer ningún dato de interés al objeto de nuestro estudio; con la salvedad de que se le otorga el calificativo de alquería, lejos todavía del rango urbano que predicamos para época nazarí.

Que sepamos el poeta Šākir ibn Muḥammad ibn al-Ḥasan ibn Muḥammad ibn Kāmil alHadramī, también llamado Abū 1-Husayn y conocido por Ibn al-Fajjar, era tío materno del maestro Abū Bakr Ibn Daḥmān. Se exaltan sus virtudes y cualidades personales y se deja constancia de su estrecha amistad con Abū 'Alī Ibn Kisrà.

Šākir fue acusado de estar implicado en el levantamiento que, en 1190, inició Alī alŶazīri contra los almohades en Marrakech y se extendió luego por al-Andalus encontrando adeptos. Sus biógrafos cuentan que fue llevado esposado con otros desde Málaga a Sevilla tras producirse lo que llaman "la desgracia de al-Ŷazīri", y que murió a consecuencia del miedo que aquello le produjo. Šākir falleció en Sevilla en 586/1190$01 \mathrm{y}$, aunque fue liberado, nunca consiguió reponerse de ello. Los autores árabes, entre ellos Ibn 'I ç̣ārī, ponen de manifiesto que los seguidores de al-Ŷazīi pertenecían a la más baja ralea; no obstante las fuentes silencian por qué se adhirió a este movimiento un personaje de estas características ${ }^{33}$. Que sepamos Šăkir cultivó en vida tanto la prosa como la poesía, llegó a ser nombrado visir en tiempos de al-Mansūr y fue hijo del eminente escribano y poeta malagueño Abū 'Abd Allāh Ibn al-Fajjār ${ }^{34}$.

Abundante información se conoce sobre la vida y obra de su notable padre, fallecido en el año 539, también conocido como Ibn al-Fajjār (el hijo del alfarero). Sobre su hermana tan sólo se conoce que se casó con Abū 'Āmir Daḥmān y que de ese enlace tuvieron a un hijo, llamado Abū Bakr Ibn Daḥmān, quien también cultivó la poesía como su tío ${ }^{35}$.

En lo tocante al poeta malagueño y katib Abū 'Alī Ibn Kisrà, fallecido en 1207, se conservan interesantes noticias en la Ihâța de Ibn al-Jatīb, que lo califica de poeta excelso y prolijo en las formas poéticas postclásicas. No pasa por alto a sus maestros y

\footnotetext{
${ }^{33}$ CALERO SECALL, María Isabel - "Málaga almohade: Políticos y ulemas". in ÁVILA, Ma Luisa y FIERRO, Maribel (eds.) - Biografias Almohades II, Estudios Onomásticos de al-Andalus. Madrid, 2000, pp. 285-314.

${ }^{34}$ IBN 'ABD AL-MALIK - Dayl. IV, op. cit., p. 238.

${ }^{35}$ LIROLA DELGADO, Jorge - "Ibn al-Fajjār al-Mālaqî̀". in Biblioteca de al-Andalus, de Ibn al-Dabbāg a Ibn Kurz. Almería, 2004, pp. 91-93.
}

Medievalísta online $N^{\circ}$ 19| Janeiro - Junho 2016 ๑ IEM - Instituto de Estudos Medievais 14 
discípulos, y resalta su condición de niño precoz, bien relacionado en ambientes cortesanos $^{36}$.

De manera testimonial cabría añadir para época almohade que, en el catálogo de manuscritos árabes de la biblioteca de El Escorial, confeccionado en el siglo XVIII por el arabista Miguel Casiri, con la trascripción propia de la época, se recoge a un personaje malagueño llamado "Mohamad b. 'Ali b. Joseph b. Monthreph Alamvi” que fallece en Dacuan en el año 636/1239 y seguidamente recoge a otro literato malagueño llamado Mohamad b. 'Ali al-Gassani, más conocido como Ibn 'Askar, que falleció en ese mismo año de 1239. Se concreta de ello que existen dos literatos malagueños llamados Muhammad b. 'Al̄̄ y que ambos fallecen en 636/1239. Lo sorprendente es que, en esta reseña, aparece por vez primera publicado el topónimo Dakwān, aunque aún no se sabe identificar con nuestra población, y además lo hace reproduciendo su grafía árabe y ubicándola correctamente al occidente de Málaga ${ }^{37}$. En todo caso, nosotros no vamos a profundizar en esta duplicidad, aunque difícil sería justificar el posible error en una mala lectura.

Siglos antes, bajo el reino zirí de Granada, es muy posible que, en la cercana alquería de Ardite, naciera el afamado gramático Ibn al-Tarawa. Señalaba tiempo atrás el historiador don Manuel Gómez Moreno que "Arìt, en Yācūt, es Ardite, alquería en término de Guaro, en la hoya de Málaga, despoblada desde antes de la conquista"38. Dice literalmente la traducción del $M u$ 'ŷàm al-buldān escrito por Yāqūt (ca. 11791229):

Arḍīt. Así lo he encontrado escrito en los textos andalusíes, pero yo dudo en la letra ya que este carácter sólo existe en lengua árabe. Con este nombre se conoce una alquería de Málaga. En ella nació el gramático (al-naḥwī) Abū l-Ḥasan Sulaymān b. Muḥ. Ibn al-Tarāwa al-Sabā'̄̄ al-Mālaq̄i al-Ardịṭ̂̀, maestro destacado de los andalusíes de su época ${ }^{39}$.

\footnotetext{
${ }^{36}$ VELAZQUEZ BASANTA, Fernando Nicolás - “Abū ‘Alī al-Hasan Ibn Kisrà. Vate popular malagueño de época almohade”. in Al-Qantara. vol. 20 (1999), pp. 201-214.

${ }^{37}$ CASIRI, Miguel - Biblioteca Arábico-Hispánica escurialensis. Vol. II, Madrid, 1760-1770, p. 126.

${ }^{38}$ GÓMEZ MORENO, Manuel - "La desinencia "it" a propósito de Madrid". in Revista de la biblioteca, archivo y museo [de Madrid]. vol. 15 (1946), pp. 7 y 8.

${ }^{39}$ YĀQŪT AL-HAMAWĪ - Mu 'ŷām al-buldān. Vol. I. Leipzig, 1866-1873, p. 208, trad. en Gamal 'Abd al-Karīm - "La España musulmana en la obra de Yāqūt (s. XII-XIII). Repertorio enciclopédico de
} 
En el estado actual de la investigación no queda claro su lugar de nacimiento. Indican los autores que nació en la cercanías de Málaga, o acaso en Salé. Si bien, la nisba geográfica que porta este personaje (al-Ardītī), en consonancia con la reseña de Yācūt, no deja lugar a dudas sobre su relación con esta pequeña unidad poblacional situada en la Garbía malagueña.

Hoy sabríamos precisar su secuencia onomástica: Abū 1-Ḥusayn (Abū 1-Ḥasan, según algunos) Sulaymān b. Muḥammad b. 'Abd Allāh al-Sabā’̄ al-Mālaqī al-Ardịțī, más conocido como Ibn al-Tarawa, nacido en Ardite hacia 1044-45 y fallecido a edad muy avanzada en Málaga, el 16 julio-14 agosto-12 septiembre de 1132 ó 25 junio-24 julio-22 agosto de 1134. Destacó como eminente gramático, experto en léxico y hombre de letras dotado para la poesía y la prosa artística, se dedicó a la enseñanza y se le conoce como autor de cinco obras ${ }^{40}$.

\section{Injerencia Meriní}

Las primeras noticias que conocemos sobre Dakwān en periodo nazarí las trae Ibn Abī Zar' y son completadas por Ibn Jaldūn, a raíz de diversos acontecimientos ocurridos durante las campañas militares del sultán benimerín Abū Yūsuf, socorrido por Alfonso $\mathrm{X}$, por entonces enfrentado contra el sultán nazarí Muhammad II, aliado éste con el infante de Castilla don Sancho.

El sultán de Fez, Abū Yūsuf, controló la tierra de Málaga y parte de la Garbiyya más o menos durante el año que va de febrero de 1278 a febrero de 1279. Quedaba aún pendiente la plaza de Málaga y ello provocó una nueva campaña contra el reino de Granada. Era ésta la segunda campaña militar de la cuarta expedición a la península y el sultán benimerín consiguió de nuevo una ayuda militar del rey Alfonso X, ayuda que la Crónica del rey Sabio cifra en 600 caballeros. Con ella salió de Algeciras el 1 de abril de 1283 y se dirigió contra Málaga y sus alrededores, atacando entre otras las fortalezas de Cártama, Coín y Fuengirola.

ciudades, castillos y lugares de al-Andalus extraído del Mu ‘yām al-buldān (Diccionario de los países)". in Cuadernos de Historia del Islam. vol. 6 (1974), 65, $\mathrm{n}^{\circ} 11$.

${ }^{40}$ PEÑA MARTíN, Salvador - "Ibn al-Tarawa, Abū 1-Husayn". in Biblioteca de al-Andalus. Vol 5. Almería, 2004, $\mathrm{n}^{\circ} 1.253$, pp. 485-488. Véase algunos versos de Ibn al-Tarawa traducidos al inglés en IBN KHALLIKAN - Ibn khallikan's biographical dictionary. Vol. II. Paris, 1843, p. 566.

Medievalísta online $N^{\circ}$ 19| Janeiro - Junho 2016 ๑ IEM - Instituto de Estudos Medievais 16 
Y el primero de muḥarram de 682 (1 de abril de 1283) fue contra Málaga y expugnó en sus alrededores muchos castillos, entre otros a Cártama, Dakwān y Suhail. Este año se alió el hijo de Alfonso con Ibn al-Ahmar, por causa de la alianza de su padre con el emir de los musulmanes Abū Yūsuf -Allāh tenga de él misericordia $-{ }^{41}$.

Sorprendentemente la ofensiva contra Málaga, al poco tiempo, quedará interrumpida por la reconciliación entre ambos sultanes. No obstante, un par de años después, al final de la quinta expedición, se decidió enviar destacamentos militares que vigilaran ciertos puntos claves en la frontera entre el reino granadino y la posesiones benimerines en la península. Siendo así cómo, en los últimos diez días del mes de ramaḍān (sobre la última semana de noviembre de 1285), Abū Zayyān Mindīl, hijo del sultán benimerín, llegó a establecerse cerca de Coín, con orden expresa de no provocar conflictos con el sultán nazarí ${ }^{42}$.

Nos dice el Rawd al-Qirțās de Ibn Abī Zar" que "en la última decena de ramaḍān de 684/20 a 29 de noviembre de 1285 envió el emir de los musulmanes a su hijo Abū Zayyān con un poderoso ejército a apostarse en la frontera entre su territorio y el de Ibn al-Ahmar, y le mandó que no se metiese en tierras de Ibn al-Ahmar ni le hiciese daño. Abū Zayyān se fue al castillo de Dakwān, al oeste de Málaga, y acampó en sus afueras" $^{\prime 43}$. El prestigioso historiador Ibn Jaldūn por su parte corrobora esta movilización de tropas bajo bandera meriní ${ }^{44}$.

Justo al año siguiente, el nuevo sultán Abū Ya'qub, sucesor de Abū Yūsuf, concertó la paz con Muhammad II y acordó la restitución por parte meriní de la mayoría de los territorios que dominaba en la península, salvo Algeciras, Tarifa, Ronda y Guadix. No

\footnotetext{
${ }^{41}$ IBN ABĪ ZAR' - Rawd al-qirtās. Rabat, 1973, p. 338, trad. de HUICI MIRANDA, Ambrosio -Textos medievales. 13, vol. 2, Valencia, 1964, p. trad. 637.

${ }^{42}$ MANZANO RODRÍGUEZ, Miguel Ángel - La intervención de los benimerines en la Península Ibérica. Madrid, 1992, pp. 73, 102 y 358-361.

${ }^{43}$ IBN ABĪ ZAR' - Rawd al-qirtās. Rabat 1973, p. 373, trad. de HUICI MIRANDA, Ambrosio -Textos medievales. 13, vol. 2. Valencia, 1964, p. trad. 683.

${ }^{44}$ IBN JALDŪN - 'Ibar VII: Kitāb al-'Ibar, Bulāq. vol. VII, ed. 1867, p. 278, trad. parcial francesa en McGUCKIN de SLANE - Histoire des Berbères et des dynasties musulmanes de l'Afrique septentrionale. Vol. IV. Alger, 1856, p. 119. Dice así la traducción francesa: "Aprés les cérémonies du ramaḍān, Abū Yūsuf pourvut a la sureté de ses places frontieres en y etablissant des garnisons. Toutes ces tropees étaient plaçées sous les ordres de l'émir Abū Zayyān Mindīl qui, d'aprés la recommandation de son père, le sultan, fixa son séjour dans Zekouan, près de Málaga, mais avec la défense formelle de toucher en aucune façon aux possessions d'Ibn-el-Ahmer".
}

Medievalísta online $\mathrm{N}^{\circ}$ 19| Janeiro - Junho 2016 ๑ IEM - Instituto de Estudos Medievais 17 
obstante, apunta el profesor Miguel Ángel Manzano que, si bien se mandaron efectivos militares a Coín y Estepona, no resulta clara la gestión directa de estas poblaciones por parte del sultán de Fez porque, en caso contrario, cabría esperar información explícita sobre ellas en las crónicas dinásticas.

\section{Un cadí de los Banū Manzūr}

Avanzando en el tiempo conocemos otra interesante noticia bien entrado el siglo XIV. Se trata de la presencia en Dakwān de un cadí perteneciente al célebre linaje de los Banū Manzūr, con ocasión de formularse una consulta jurídica desde el castillo de Teba, según se recoge en una fatwà, fechada en 20 dī l-hiŷŷa de 735 (agosto de 1335), compilada por al-Wanšarīsī en su colección de dictámenes jurídicos $M i^{6} y \bar{a} r a l-m u^{6} r i b^{45}$.

Del simple dato se desprende que Dakwān bien pudo ser sede del cadiazgo de la Garbía malagueña, aunque no se puede afirmar con certeza, pues si bien conocemos los nombres de algunos de estos cadíes, los textos árabes nunca llegan a especificar dónde radicaba la sede ${ }^{46}$. En esta línea también se plantea si resulta verosímil extender la jurisdicción de este cadí hasta la lejana población de Teba, que por entonces había caído en manos castellanas ${ }^{47}$.

De cualquier modo, sería legítimo pensar que fuera cadí de la Algarbía o tal vez de cualquier otra ciudad cercana a la frontera con Castilla, pues como nos dicen unos vecinos de Benaoján "la jurisdicción era su persona donde estuviera"48, así que nada impide afirmar que el cadí Abū Bakr ostentaba y ejercía competencia territorial sobre Coín y su alfoz.

Respecto a esta consulta en Derecho, serán los cadíes residentes en Coín y Málaga los encargados de resolver la controversia jurídica, ambos integrantes de una conocida y

\footnotetext{
${ }^{45}$ AL-WANŠARĪSĪ - Al-Mi' yār al-mu'rib wa-l-yāmi' al-Mugrib 'an fatāwà ahl Ifrīqiya wa-l-Andalus wa-l-Magrib. Vol. III. ed. M. Ḥaŷŷi. Rabat, 1981, p. 176.

${ }^{46}$ CALERO SECALL, M M Isabel - "Sedes judiciales malagueñas en época nazarí". in Baética. 7 (1984), pp. 355-365.

${ }_{47}$ MARTÍNEZ ENAMORADO, Virgilio - "El Medievo. Entre dos sistemas: islamización y castellanización”. in GARCÍA ALFONSO, E. et alii (eds) - El bajo Guadalteba (Málaga): espacio y poblamiento. Una aproximación arqueológica a Teba y su entorno. Málaga, 1995, pp. 285-287 y 290292.

${ }^{48}$ ACIÉN ALMANSA, Manuel - Ronda y su serranía en tiempos de los Reyes Católicos. Tomo I. Málaga, 1979, p. 127.
}

Medievalista online $N^{\circ} 19 \mid$ Janeiro - Junho 2016 @ IEM - Instituto de Estudos Medievais 18 
prestigiosa familia de juristas establecidos en la capital malagueña, los Banū Manzūr. El consultante es el cadí Abū Bakr Muhammad b. Manzūr, que se encuentra instalado en Coín, desde donde formula la pregunta. Y la contestación definitiva la da el cadí de Málaga 'Uțmān b. Manzūr, que, debido a una enfermedad que le aquejaba, no pudo escribir la respuesta de su puño y letra, falleciendo ese mismo año al poco tiempo.

Que sepamos Abū Bakr Ibn Manzūr fue cadí de Málaga y jațīb de su alcazaba, así como un prestigioso tradicionista y literato. Escribió varias obras sobre Derecho y emitió numerosos dictámenes jurídicos recogidos por al-Wanšarīsī. Como decíamos, pertenecía a una ilustre y prestigiosa dinastía de cadíes, de cuya nobleza dan testimonio numerosos textos medievales. Originarios de Sevilla, los Banū Manzūr fueron una de las familias andalusíes célebres por su nobleza y sabiduría, que se vieron obligados a emigrar a Málaga ante el avance cristiano. Se cree que llegaron hacia el año 646/1248 cuando Fernando III toma Sevilla dando a sus habitantes un plazo de un mes para abandonar la ciudad.

En Málaga nació Abū Bakr Muhammad Ibn Manzūr en fecha desconocida y en Málaga ejerció el cadiazgo, cargo que, después de él, desempeñarían tres de sus descendientes. Igualmente se sabe que fue cadí en otros varios lugares, entre ellos probablemente la Garbiyya malagueña, pues, como vimos, residía en Coín y ejercía desde aquí hacia el año 1330.

Entre sus discípulos se cuentan sus propios biógrafos Ibn al-Jațīb y al-Bunnāhī, que no escatiman elogios a su persona. Según afirman estos, Abū Bakr Ibn Manzūr era un juez experimentado y competente, versado en la redacción de contratos, de método y conducta loables, y firme en sus decisiones. A pesar de su cargo, prestigio y sabiduría, se distinguió por su gran humildad y falta de soberbia, su bondad extrema y su generosidad con los más vulnerables. Falleció en Málaga a principios de mayo de 1349, víctima de la peste que asoló la península ese año. Dice Ibn al-Jaṭịb que Abū Bakr Ibn Manzūr compuso prosa y poesía. Las fuentes escritas mencionan varios títulos de este autor, mayormente de tema religioso, jurídico y sufí. En nuestros días, de sus obras se conservan manuscritos en las Bibliotecas de Rabat, Tetuán y El Escorial, aunque la 
verdad es que se conocen unas seis obras de su puño y letra, además de ciertas poesías hoy desaparecidas ${ }^{49}$.

La definitiva respuesta a la consulta jurídica planteada desde el castillo de Teba y formulada por Abū Bakr la dará el anciano cadí de Málaga Abū 'Amr 'Uṭmān b. Manzūr, que había sido cadí de Vélez, Bentomiz, Comares y Málaga sucesivamente. Murió en la ciudad de Málaga el martes 25 de $d \bar{u}$ l-hiŷŷa de 735 (15 de agosto de 1335). Según la mayoría de sus biógrafos siendo cadí, si bien al-Bunnāhī precisa que había sido sustituido a principios de ese mismo año (hacia septiembre de 1334). Las fuentes biográficas destacan que tras su muerte no hubo en Málaga nadie como él en amplitud de conocimientos e inteligencia ${ }^{50}$. Digno de mención es que ese mismo año de 1335 ordenó escribir la respuesta jurídica a la consulta planteada, siendo ésta resolución de las últimas que emitió, acaso la última, cercana ya la fecha de su muerte e impedidas ya sus manos para poderla redactar.

\section{Descripciones literarias}

Muy conocidos para la historiografía son los elogios, bastante expresivos, que le dedican a esta población autores como Ibn Batṭuțta e Ibn al-Jațīb. Son éstas las primeras descripciones históricas que se tienen sobre el Coín andalusí y todas ellas datan de mediados del siglo XIV. Sin duda alguna, uno de los testimonios que se conservan de mejor provecho para nuestra historia es la breve reseña realizada por el viajero Ibn Batțūta. Su relato se detiene en esta población, celebrando sus riquezas y ubicándola en el mundo conocido. Debió ser entre los años 1349-1350 cuando visitó Dakwān dejando de su pluma el siguiente pasaje: "Desde Granada me trasladé a Alhama, luego a Vélez, a Málaga y a la fortaleza de Dakwān, que es buen castillo, abundante en aguas, árboles y frutas" ${ }^{\prime}$. La visita la realiza en el camino de vuelta desde Granada a Gibraltar, pasando por aquí en el trayecto de Málaga a Ronda. Y sus impresiones se reflejan fielmente en el tomo IV de su obra Tufhat al-nuzzār, más conocida como la Riḥla de Ibn Bațtūṭa.

\footnotetext{
${ }^{49}$ ÁVILA, María Luisa - "Los Banū Manzūr al-Qaysī”. in MARÍN, Manuela y ZANÓN, Jesús (Eds.) Estudios Onomásticos-biográficos de al-Andalus (familias andalusies), n ${ }^{\circ}$ V. Madrid: 1992, pp. 23-37; PENELAS, Mayte - "Ibn Manzūr, Abū Bakr". in LIROLA DELGADO, Jorge (dir) - Biblioteca de alÁndalus. Vol. 4 - de Ibn al-Labbāna a Ibn al-Ruyūll̄’. Almería, 2006, pp. 107-110; CALERO SECALL, $\mathrm{M}^{\mathrm{a}}$ Isabel - "Dinastías' de cadíes en la Málaga Nazarí". in JÁBEGA. no 55 (1987), pp. 3-14.

50 Ibidem.

${ }^{51}$ IBN BATTṬUTṬA - Tufhat al-nuzzār fì garā'ib al-amsār wa- 'ayā'ib al-asfār. tomo IV, París, 1854, pp. 373-374, trad. en FANJUL, S. y ARBÓS, F. - A través del Islam. Madrid, 1981, p. 765.
} 
Si bien, nada comparado con las atentas palabras que dedica a Dakwān el sabio polígrafo Ibn al-Jațīb (1313-1374) en su conocida obra Mi'yār al-ijtiyār, donde nos habla de la cualidad de sus habitantes, de las infraestructuras urbanas (murallas y edificios) y de los medios de producción (molinos, frutas y manjares).

Dije:

- ¿Y Coín?

Contestó:

Jardines y estanques. La excelencia de sus frutas está por cima de toda ponderación. Sus edificios son como Jawarnaq y Sadir. Es como una amplísima mesa llena de exquisitos manjares. Las piedras de sus molinos ruedan constantemente y los árboles son tan espesos que sus ramas se enlazan en estrecho abrazo. Sopla allí una suave brisa. En fin. La fama de esta ciudad se pregona por el mundo, como ondea a todo viento un estandarte.

Sin embargo, su posición constituye una esperanza para el enemigo: es el grano que está sobre la tierra esperando el pájaro que se lo engulla, porque sus murallas son insuficientes para defenderla. Sus edificios son de nueva planta y quienes los habitan y lo que hay dentro de ellas, carecen de solera ${ }^{52}$.

No sabemos cuántas veces visitó Ibn al-Jațīb esta población, aunque con toda seguridad detectamos su presencia aquí en 1359 con unos 46 años, tras el golpe de estado que destronó al sultán Muḥammad V. Que sepamos, el sabio llegó a reunirse con el depuesto sultán en Guadix con la esperanza de exiliarse en el Magreb e hicieron juntos el camino de Antequera a Marbella pasando por Coín.

Existe también cierta reseña genérica a Dakwān en la obra titulada Dikr Bilād alAndalus (Una descripción anónima de al-Andalus), escrita en árabe en el siglo XIV usando textos del siglo XI, a cuya época debemos remontarnos. Según los últimos estudios de F. N. Velázquez Basanta es probable que esta obra anónima e inconclusa

\footnotetext{
${ }^{52}$ IBN AL-JAṬ̄̄B - Mi yār al-ijtiyār fì dirk al-ma āhid wa-l-diyār, en Mušāhadāt Lisān al-Dīn b. alJațīb fì bilād al-Magrid wa-l-Andalus (Maymū'a min rasā'ila-hu). Ed. Aḥmad Mujtār al-'Abbādī. Alejandría, 1983, p. 67, trad. Mohammed Kamal Chabana, Marruecos, 1977, p. 138. MARMOLEJO CANTOS, Francisco - Históricas y arqueológicas del Medievo en Coín. Málaga, 2009.
}

Medievalista online $\mathrm{N}^{\circ}$ 19| Janeiro - Junho 2016 @ IEM - Instituto de Estudos Medievais 21 
fuera escrita por el literato y poeta granadino Ibn Ŷuzayy entre 1353-1356. Dice así el texto original:

Entre sus castillos y ciudades (las de Rayya), se cuentan Marbella, Suhayl, Cártama, Comares, Vélez-Málaga, Dakwān, Alhama, Antequera y Estepa, todos ellos son castillos inaccesibles que producen grandes cantidades de higos, aceitunas, almendras, uvas y granadas ${ }^{53}$.

En consonancia con las fuentes andalusíes que ponderan la vida agrícola, artesanal y comercial del Coín nazarí, se percibe también en la trama urbana de los siglos XV y XVI esa vitalidad mercantil que le dio fama "por el mundo, como ondea a todo viento un estandarte". La ciudad castellana que se superpone a la nazarí, si bien altera el espacio urbano y sus ejes principales, preserva gran parte de esas primitivas instalaciones comerciales y artesanales, muchas apartadas del núcleo habitado, ocupando los espacios productivos inmediatos a la ciudad, a la vez que incorpora y redistribuye nuevas infraestructuras por su entramado, arrabales y periferia, contando con hospital, mancebía, escuela, cárcel, carnicerías, herrerías, jabonerías, ventas y mesones.

\section{Reinados del sultán nazarí Muhammad V de Granada}

La fortaleza de Coín será referente para el sultán Muhammad V, por aquí estuvo de paso en su huida cuando fue destronado y aquí regresará años después para tomar su castillo, entre algunos otros, con la esperanza de recuperar su reinado en al-Andalus. Tras el golpe de estado de Ismā‘il II, el depuesto sultán Muḥammad V logró huir al Magreb acompañado por un numeroso séquito, a pie y a caballo, junto a su gran visir Ibn alJațīb. Salieron desde Guadix el 4 de noviembre de 1359/12 de dī l-hiŷŷa de 760, pasando por Loja, Antequera, Coín y Marbella, de donde embarcaron con destino a

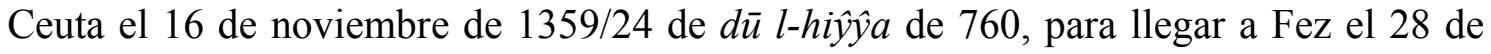
noviembre del mismo año (6 de muharram de 761).

\footnotetext{
${ }^{53}$ ANÓNIMO - Dikr Bilād al-Andalus. (Una descripción anónima de al Andalus). Edic. y trad. de Luis MOLINA. Madrid: CSIC, 1983, p. 68 y pp. trad. 73 y 74.
}

Medievalísta online $N^{\circ} 19 \mid$ Janeiro - Junho 2016 @ IEM - Instituto de Estudos Medievais 22 
Cuando tuvo lugar el golpe de estado a finales de agosto de 1359, Ibn al-Jațīb fue encarcelado y sus bienes confiscado; el sultán en cambio logró escapar del peligro y huyó con nocturnidad a Guadix, con la única compañía de unos jóvenes esclavos de su servicio. Allí fue cercado y sitiado por contingentes militares; aunque sus adeptos lograron contener los ataques, no sin sacrificios. Ibn Marzūq, secretario del sultán meriní Abū Salim, intercedió por Ibn al-Jațīb, que fue liberado y consiguió reunirse con el sultán en Guadix. El viaje empezó el segundo día de la fiesta de al-Naḥr del año mencionado, haciendo una parada en Fahs al-Funt, después se trasladaron a Loja, a Antequera, luego a Dakwān, a Marbella, y en cada uno de estos pueblos reinaba un ambiente de nostalgia y pesadumbre por este distanciamiento. Se embarcaron en la mañana del día 24 del mismo mes y llegaron a Ceuta agradecidos por haber sobrevivido $^{54}$.

Con la esperanza de recuperar su reinado, el destronado sultán pronto puso fin al exilio y regreso a al-Andalus para enfrentarse a Muḥammad VI, que había sustituido a Ismā‘il II en el trono de La Alhambra. Decidió para ello establecerse en Ronda seguido de una imponente tropa con cientos de mercenarios bien pertrechados y emprendió una serie de ataques contra el reino granadino hacia el año 1362, con el fin de sumar adeptos y distritos a su causa.

Reseña el polígrafo Ibn al-Jațīb en el tomo III de su Nufāạat cómo Muhammad V tomó la fortaleza de El Burgo, que se encuentra entre Málaga y Ronda, para luego marchar sobre Casarabonela. Durante diez días atacaría de manera incesante todo enclave que no estuviera sometido a su autoridad.

Y el sultán se puso en marcha seguido de una muchedumbre, y la gente acudía [a ver pasar el cortejo], y se sometieron las célebres fortalezas [de la Algarbía de Málaga] como Dakwān, Cártama, Tolox, Mijas (y) al-M.nšāt. Tras la resistencia de dos o tres días de asedio [por parte de quienes estaban] en las alcazabas, apretó el cerco para conseguir que se rindieran ${ }^{55}$.

\footnotetext{
${ }^{54}$ IBN AL-JAṬĪB - Al-Ihāta fi ajbār garnāta. Vol. II. El Cairo, 1974, p. 28. Véase MARMOLEJO CANTOS, Francisco - Históricas y arqueológicas del Medievo en Coín. Málaga, 2009, p. 46; idem - La Edad Media en Coín y su alfoz. Málaga, 2014.

${ }^{55}$ IBN AL-JATT̄̄B - Nufādat al-ŷirāb fi 'ulātat al-igtirāb. Vol. III. Casablanca, 1989, p. 118. Véase MARTÍNEZ ENAMORADO, Virgilio - "La Algarabía como realidad geohistórica...”, pp. 57-94; ídem -
}

Medievalista online № 19| Janeiro - Junho 2016 @ IEM - Instituto de Estudos Medievais 23 
Debieron ser estas plazas de interés estratégico para recobrar su reinado tras el exilio. Finalmente regresó a Granada el 16 de marzo de ese mismo año, fue reconocido nuevamente sultán y reanudó sus relaciones diplomáticas consolidándose en el trono.

Será apenas unos años después, hacia 1364, cuando el sultán granadino reciba a Idrīs b. 'Uṭmān b. Abī 1-'Ulá en su corte y le nombre šayj al guzāt de Málaga, confiándole la defensa "de los distritos occidentales, Ronda y Dakwān y sus términos de un modo exclusivo e independiente, con amplio e ilimitado poder para conducir a todos ellos hacia la guerra santa".

Ibn al-Jaṭīb en su Rayḥānat recoge el decreto (zahīr) por el cual Idrīs b. 'Uṭmān b. Abī l'Ulá es nombrado comandante de los voluntarios de la fe en Málaga y se le confía la defensa de los distritos occidentales de Ronda y Coín.

le nombra comandante de los voluntarios de la fe, combatientes de la guerra santa, y primer jefe para la defensa de la religión en la ciudad de Málaga, hermana de la capital de su reino, segunda perla preciosa de su collar [...], confiándole el cuidado de los distritos occidentales, Ronda y Dakwān y sus términos de un modo exclusivo e independiente, con amplio e ilimitado poder para conducir a todos ellos hacia la guerra santa, obrando según su gloria en toda situación $[\ldots]^{56}$.

Más concretamente esta noticia, que fue traducida por M. Gaspar Remiro, alcanza todo su significado al mencionar explícitamente a Coín como cabeza militar del distrito occidental de Málaga, lo que venimos llamando al-Garbiyya. Pese a que no conocemos la fecha exacta de su nombramiento, habrá que convenir que Idrīs estuvo muy poco tiempo en el cargo, pues en 1364 fue liberado de las atarazanas de Sevilla donde estuvo encarcelado, siendo por aquel entonces acogido por el sultán Muḥammad V, quien le nombra šayj al guzāt de Málaga y le confía la defensa de los distritos de Ronda y Coín.

"Dos fortalezas andalusíes de la algarabía malagueña en la Nufāḍat al-ŷirāb de Ibn al-Jatīb: Tolox y Yunquera". in VELÁZQUEZ BASABTA, Fernando N, y LÓPEZ Y LÓPEZ, Ángel C. (eds.) Aynadamar. Colección de Estudios e Textos Árabes. I. Cádiz, 2002, p. 325.

${ }^{56}$ IBN AL-JAȚĪB - Rayhānat al-kuttāb wa-nây'at al-muntāb. Trad. en GASPAR REMIRO, Mariano "Correspondencia diplomática entre Granada y Fez (siglo XIV). Extractos de la 'Reihanat alcuttab"”. in Revista del Centro de Estudios Históricos de Granada y su Reino. (1916), p. 411. 'ABBĀDĪ, Aḥmad Mujtār al- - "El Reino de Granada en la época de Muhammad V", p. 61, 32 y 237. TORRES DELGADO, Cristóbal - "El ejército y las fortificaciones del reino Nazarí de Granada". in Gladius, Vol. Especial (1988), p. 209.

Medievalista online $N^{\circ} 19$ | Janeiro - Junho 2016 ๑ IEM - Instituto de Estudos Medievais 24 
Sin embargo, justo al año siguiente, Alī b. Badr al-Dīn accedió a la šiyāja de Málaga y Granada y ésta es razón más que suficiente para pensar que Idrīs ya había abandonado el cargo, marchando entonces a Ceuta y luego a Fez, donde murió estrangulado a los pocos años ${ }^{57}$.

Ese año de 767/1365-66 tuvieron lugar diversas campañas contra tierra de infieles (cristianos) contando con la participación activa de Dakwān y los pueblos de su entorno. La frontera de El Burgo, que cayó en manos del enemigo por aquellos años, auguraba el aislamiento de la ciudad de Ronda y fueron llamados al combate las gentes de la Garbiyya malagueña y de Ronda, "y lo que está entre ellas; y Dios facilitó su victoria después de un combate encarnizado, una terrible batalla, una guerra santa memorable" ${ }^{, 58}$.

\section{Amenazas y divisiones en tiempos del sultán Muḥammad IX el Zurdo}

La frontera retrocede ante el avance cristiano y la población andalusí se repliega y concentra en las vegas de Río Grande y Guadalhorce. Sucesivas algaradas tuvieron lugar por el Val de Cártama y el de Santa María aprovechando las debilidades de la frontera y las disputas internas por el trono de La Alhambra. Relata con pormenores la Crónica de don Juan II de Castilla que, entre los meses de primavera a verano del año de 1433, reinando por tercera vez el sultán Muhammad IX el Zurdo, la guarnición de Dakwān, formada entonces por más de 500 caballeros de la milicia real, sale de su fortaleza matando a más de 200 cristianos ante los muros de la misma población.

Todo se inicia cuando el adelantado Gómez de Ribera decidió partir con sus huestes desde Écija para talar nuevamente la vega malagueña. Sin encontrar resistencia alguna asentó el real en un lugar que decían el Cerro de los Pendones, entre Alhaurín y Cártama $^{59}$. Acto seguido, los herberos o segadores fueron a cortar hierba para el real, probablemente para alimentar a los caballos, y a talar panes allá donde se encontraran.

\footnotetext{
${ }^{57}$ MANZANO RODRÍGUEZ, Miguel Ángel - La intervención de los benimerines en la Península Ibérica. Madrid, 1992, pp. 358-361.

${ }^{58}$ IBN AL-JAṬīB - Al-Ināta fì ajbār garnāta. Vol. II. El Cairo, 1974, p. 78. GASPARIÑO GARCÍA, Sebastián y BENITO DE LOS MOZOS, Federico - "Nota sobre una nueva ceca para las monedas nazaríes: Ronda. Ensayo de su atribución". in Omni, 3 (2011), pp. 63-69.

${ }^{59}$ En los libros de Repartimiento se cita el cerro en cuestión en término de Casarabonela, aunque quizá el topónimo este representado por diversos lugares.
}

Medievalísta online $N^{\circ} 19 \mid$ Janeiro - Junho 2016 @ IEM - Instituto de Estudos Medievais 25 
Se envió para su protección a 200 caballeros capitaneados por el hidalgo zamorano Juan de Portocarrero, junto a 300 peones, de los que iban al herbaje y a talar, capitaneados estos por un caballero del adelantado llamado Gonzalo Tello.

Y por cuanto iban a Coín y Alhaurín, donde sabían que se había concentrado mucha gente a caballo de Málaga y de otras partes, el adelantado ordenó que no se acercasen a estos lugares, ni comenzasen escaramuzas y, si notaban la presencia de muchos enemigos, que rápidamente dieran aviso y que él iría luego a socorrerlos con todas las fuerzas del real. Sin embargo el caballero Juan de Portocarrero no acató las órdenes del adelantado y se plantó con sus jinetes ante los muros de Dakwān, desde donde salieron más de 500 caballeros del sultán embistiendo contra la caballería cristiana, así hasta que volvieron la espalda y huyeron a la fuga en desbandada con dirección al real. Los peones castellanos se encontraban preparados detrás de los caballeros, en formación para la batalla, pero fueron arrollados durante la estampida por su propia caballería ${ }^{60}$.

La guarnición de Dakwān continuó cabalgando para dar alcance a los cristianos. Nadie hubiera quedado vivo de no ser porque, ya próximo al real, el adelantado lo supo y salió a socorrer a los suyos. No fue hasta entonces cuando la caballería nazarí tocó a retirada y emprendió el regreso a Coín tras una gran victoria. Según relataba el contador del Rey fallecieron más de 200 castellanos, entre ellos el capitán de los peones Gonzalo Tello. Quedaron sobre el campo de batalla muchos cadáveres de caballeros y "peones que iban a la guarda, e de los que talaban, e de los herberos, e de los pajes asaz" y otros muchos quedaron cautivos.

El adelantado decidió levantar el real para regresar a Écija, pero, apenas unos días después, entró nuevamente en tierra de Málaga para vengar la derrota y taló panizos, viñas y huertas, sin que hubiera pelea o escaramuza alguna. Justo al año siguiente, en 1434, el adelantado lo intentará de nuevo, pero encontró la muerte junto a Álora.

Según recoge Ibn 'Āsim en su Ŷunnat al-rị̂a, pocos años más tarde, Dakwān se sublevará contra el sultán Muhammad IX el Zurdo y apoyará a su sobrino el príncipe

\footnotetext{
${ }^{60}$ GARCÍA DE SANTA MARÍA, Álvar - Crónica de Juan II de Castilla. parte II. in CODOIN, vol. C (1891), pp. 382-383, 369 y 399.
} 
Yūsuf como aspirante a ocupar el trono de La Alhambra ${ }^{61}$. Las diferencias surgidas entre el sultán nazarí con su sobrino provocaran el distanciamiento entre ambos y la marcha de Yūsuf a Almería. Desde allí, el príncipe continuará cuestionando y desafiando al sultán granadino, atribuyéndose prerrogativas ajenas de manera insolente. El Zurdo, al frente de su ejército, asediará la capital almeriense, pero la fuerte resistencia del príncipe Yūsuf provoca que el sultán levante el cerco y emprenda el regreso a la capital del reino. En el trayecto de vuelta se encontró con la sublevación de Granada y Guadix; ante lo cual se encaminó a Málaga, allí encontró refugió y supo de la traición de algunos de sus partidarios, encajando la derrota de su ejército en la campiña de B.l.g.̌̌ (Peligros) con gran pérdida de vidas humanas.

Tan pronto se prodigó esta noticia, la rebelión contra el sultán estalló en Vélez Málaga, donde sus habitantes desplazaron de la alcazaba a su alcaide Ahmad b. Quṭba y "proclamaron al que estaba en la capital", osea a Yūsuf b. Aḥmad ${ }^{62}$. Las sublevaciones se extendieron a Dakwān y alrededores, incluso a Ronda y, "sin ninguna causa clara", a la propia ciudad de Málaga.

Lejos de quedar sofocadas estas revueltas, el Zurdo decidió huir hacia Álora, siendo recibido de muy buen grado, y desde allí al castillo de Casarabonela, donde buscó cobijo y finalmente abdicó a favor de su sobrino Yūsuf b. Aḥmad, que fue proclamado en Granada como Yūsuf $\mathrm{V}^{63}$. La determinación cronológica de estos acontecimientos es complicada, aunque se estima que se desarrollaron hacia el año 849/1445-1446.

El Zurdo retornaría al poder a los pocos años, por cuarta y última vez, dispuesto a mantenerse en el trono con mayor astucia que destreza y buen conocimiento de sus dominios. Siendo así que, tiempo después, cuando Málaga fue tomada por el proclamado Ismā'il III, sabemos que el sultán nazarí no toleró tal desafío y quiso recuperarla, tomando sus huestes los puertos y caminos del flanco occidental, los pasos

\footnotetext{
${ }^{61}$ IBN ‘ĀSIM - Ŷunnat al-riḍa fì l-taslìm li-ma qaddara Allāh wa-qaḍa. Vol. I. Ammán, 1989, p. 309, línea 12. Véase CHAROUITI HASNAOUI, Milouda - Edición y estudio del Kitāb Ŷunnat al-riḍā de Ibn 'Āsim de Granada. Madrid, 1988. De esta misma autora - "La intervención de la mujer en la vida política granadina durante la primera mitad del siglo XV". in I Jornadas Estudios de Frontera. Alcalá la Real y el Arcipreste de Hita. Jaén, 1997, pág. 329.

${ }^{62}$ Milouda Charouiti indica que el alcaide de Vélez Málaga no es desplazado de su alcazaba sino todo lo contrario, encabeza la revuelta contra el sultán.

${ }^{63}$ VIDAL CASTRO, Francisco - "Una década turbulenta de la Dinastía Nazarí de Granada". in DEL MORAL, Celia (ed.) - En el epílogo del Islam andalusí. La Granada del siglo XV. Granada, 2002, pp. 8691.
}

Medievalista online $N^{\circ} 19 \mid$ Janeiro - Junho 2016 @ IEM - Instituto de Estudos Medievais 27 
por Coín y Álora, antes de dirigirse contra Málaga, cortando así la ayuda exterior del adelantado de Castilla entre los meses de mayo y junio de $1450^{64}$.

\section{El poeta y jurista Ạ̣mad al-Daqqūn}

Del siglo XV conocemos un célebre intelectual y literato granadino, cuya familia fijó su residencia en la población de Coín. Su nombre completo era Abū-l-‘Abbàs Aḥmad ibn Muhammad ibn Mūsà ibn Yūsuf al-Sinhāŷ̄̄ al-Daqqūn. Nació en Granada después de la primera mitad del silgo XV y pertenecía a una familia beréber que llegó a la península y se estableció en Dakwān. No obstante pasó su juventud en la capital del reino y se distinguió como uno de los discípulos predilectos de al-Mawwāq, por cuyo método aprendió a recitar el Corán ${ }^{65}$.

El miedo y la inseguridad ante la inminente caída del reino granadino le obligó a huir de la península. Desde Málaga, en donde a la sazón habitaba con su familia, se trasladó al Magreb y estableció su residencia en Fez. En esta ciudad completó sus estudios concurriendo a la cátedra de al-Sagīr, el cual le enseñó las siete lecturas del libro sagrado. Mas tarde, muerto al-Sagīr, continuó su formación científica bajo la dirección de al-Gāzī.

Las fuentes históricas lo tratan como hombre jovial, de alegre carácter y amable trato ${ }^{66}$. Muy aficionado a la chanza, fueron sus chistes y bromas celebradísimos en Granada. Sus contemporáneos lo consideraron un eminente jurista y 'un delicado poeta, ${ }^{67}$, y en su patria adoptiva lo colmaron de honores y distinciones. Orador elocuente y sabio

\footnotetext{
${ }^{64}$ PELÁEZ ROVIRA, Antonio - Dinamismo social en el reino Nazarí (1454-1501): de la Granada islámica a la Granada mudéjar. Granada, 2006, p. 355.

${ }^{65}$ SECO DE LUCENA PAREDES, Luis - "La escuela de juristas granadinos del siglo XV". in Miscelánea de Estudios Árabes y Hebraicos. Vol. VIII (1959), pp. 27-28.

${ }^{66}$ El personaje aparece biografiado en la obra Idjaza de Qādir al-Fāsy. Véase BEN CHENEB, Mohamed - Etude sur les personnages mentionnés dans l'Idjaza du Cheikh 'Abd al-Qādir al-Fāsy. in Actes du XIV Congres International des Orientalistes. Algiers, $1905, \mathrm{n}^{0} 75$. Son fuentes imprescindibles para completar

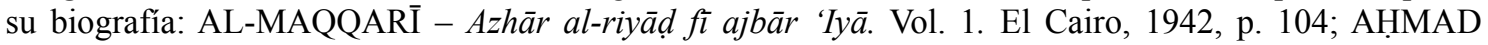
BĀBĀ - Nayl al-ibtihâŷy bi-tatrīz al-Dībāŷy. (ed. en los márgenes de Ibn Farhūn, al-Dībāîy al-muhab), p. 88; IBN AL-QĀDİ - Durrat al-hîyâl fi gurrat asmā'al-rîyâl. Vol. I. Ed. ALLOUCHE. Rabat, 1934, p. 43; IBN AL-QĀDI - Jadwat al Iqtibas. p. 66; MUHAMMAD AL-QĀDIRI - Nashr al-Mathāny I. 127; ALKATTĀNY - Salwat III, 248.

${ }^{67}$ Muy conocidos para la historiografía medieval son los dos poemas que al-Daqqūn dedica a la conquista de su tierra y que al-Maqqarī recoge en sus $A z h \bar{a} r$. Véase ABBOUD HAGGAR, Soha - "En Granada sólo quedó el llanto". in La Aventura de la historia. 39 (2002), pp. 63-66.
}

Medievalísta online $N^{\circ} 19 \mid$ Janeiro - Junho 2016 @ IEM - Instituto de Estudos Medievais 28 
teólogo, consiguió encumbrarse fácilmente en la capital mariní y pronto logró fama y fortuna, llegando a ser una de las personalidades más conspicuas de dicha ciudad, en la que alcanzó el cargo de predicador de la mezquita al-Qarawiyyīn. Falleció Aḥmad alDaqqūn en la ciudad de Fez el 1 de ša 'bān de 921 (10 de septiembre de 1515).

\section{En la frontera de Granada}

Decisiva derrota tuvo lugar en la renombrada Batalla de Lopera, en la que fueron apresados los alcaides de Málaga, Álora, Coín y El Burgo y muerto el de Vélez, además de "un caballero que se llamaba el Gebiz, e otros cabeceras e moros de los principales" ${ }^{\prime 68}$. El enemigo castellano ganó en está incursión hasta 15 banderas, dejando desprotegida y atemorizada a toda la población fronteriza. Cuenta la crónica que el enfrentamiento tuvo lugar el miércoles 17 de septiembre de 1483, en la fuente de la Higuera, cerca de Lopera, allí murieron "600 moros en trecho de una legua"69.

Los ataques contra la frontera granadina prosiguieron al año siguiente; en abril de 1484 el ejército castellano protagonizará la última correría por tierras de Dakwān. Se iniciará con la tala del circuito de Álora, aunque "la hueste pasó adelante, e talaron todos los panes e olivares e viñas e huertas e higuerales, e todos los otros árboles que hallaron en los valles e tierras de Cohin, e del Sabinal, e de Casarabonela, e de Almexia (Almogía), e de Cártama, en lo cual estuvieron diez días". Siguiendo en detalle el relato de estos hechos, la crónica añade que pusieron real sobre la villa de Coín y talaron "todo lo que fallaron en circuito della, hasta que llegaron al término de Altazayna (Alozaina), e de Gutero (Guaro), e talaron ansimesmo a Alhaurín, e destruyeron toda aquella tierra e sus comarcas" ${ }^{\text {70 }}$. Este episodio en cuestión se ha venido en llamar la 'Gran Tala', y fue emprendida por mandato del Rey con la intervención directa de unos quince mil peones cristianos, que penetraron por Álora y el val de Cártama "hasta la mar". Se prolongó durante más de quince días con muchas escaramuzas, especialmente "una que ovo Bernal Francés, capitán del Rey, en que murieron ochenta moros, los más de ellos de la

\footnotetext{
${ }^{68}$ PULGAR, Fernando del - Crónica de los Señores Reyes Católicos Don Fernando y Doña Isabel de Castilla y de Aragón. Valencia, 1780, pp. 217-218.

${ }^{69}$ BERNÁLDEZ, Andrés - Historia de los Reyes Católicos D. Fernando y D ${ }^{a}$ Isabel. Tomo I. Granada 1856, pp. 142-145.

${ }^{70}$ PULGAR, Fernando del -Crónica de los Señores Reyes Católicos..., pp. 225-226.
} 
de Coín, e ellos no mataron más de veinte caballos de los escuderos del dicho capitán"71.

Después de la rendición de Álora en junio de 1484, los moradores de Coín y Casarabonela fingieron negociar con el Rey con la esperanza de permanecer en sus viviendas y poseer libremente sus bienes como vasallos; no obstante, aprovecharon el tiempo de estas negociaciones para reforzar ambas guarniciones ${ }^{72}$.

\section{Caída final}

Bien sabían que, antes de tomar Málaga, era necesario atacar primero los castillos de Casarabonela, Cártama y Coín; porque de lo contrario "los moros harían daño en la gente que fuese a los herbajes y en los que trajesen mantenimientos". Se infiere de la crónica de Valera que la conquista de Dakwān tuvo lugar el miércoles 27 de abril de 1485 y entre los muros de la villa se cifra había unas 3.000 personas, "que hicieron muchos heridos y dieron muerte a unos 30 hidalgos de la casa del Rey" ${ }^{\text {,73 }}$. En honor a la verdad, ningún cronista pronuncia el día exacto de la rendición de Coín, ni tan siquiera Valera deja constancia expresa ${ }^{74}$. Únicamente aparece reflejado fielmente en la 'Consolatoria de Castilla' escrita por Juan Barba (1429-1489) ${ }^{75}$.

Sobre la toma de esta población se ha hablado mucho y mal, a veces tanto que se ha desvirtuado el relato histórico, usando fuentes muy tardías y lamentablemente tan sólo las crónicas de los vencedores. A ello deberíamos añadir la penosa visión del 'moro infiel y miserable' legada por los arabistas del XIX y muy perfeccionada durante la pasada dictadura. Dejamos bien claro que preferimos dedicar nuestra atención a los textos árabes y al testimonio de los vencidos, en la medida que son desconocidos, sin extendernos en remedar las agotadas crónicas de la conquista. Acudiremos por vez primera al texto anónimo de la Nubḍtal- asr y lo completaremos con la valiosa

\footnotetext{
${ }^{71}$ BERNÁLDEZ, Andrés - Historia de los Reyes Católicos..., pp. 147 y 148.

${ }^{72}$ PALENCIA, Alonso de - Guerra de Granada. Libro IV. Madrid, 1909.

${ }^{73}$ VALERA, Mosén Diego de - Crónica de los Reyes Católicos. Ed. J. de M. CARRIAZO. Madrid, 1927, cap. LX, p. 188.

${ }^{74}$ GARCİA AGÜERA, José Manuel - Crónicas de Coín. Coín (Málaga), 2000.

${ }^{75}$ Dice el texto: "en un día martes daqueste nombrado abril se pusieron los cercos escritos y estaba gran gente daquellos malditos, qu'en este Coyn se avýan juntado. Y el miércoles luego que los cercaron salieron ellos a escaramuzar y nuestros peones por bien pelear envueltos con ellos allá se lanzaron".
}

Medievalísta online $N^{\circ}$ 19| Janeiro - Junho 2016 ๑ IEM - Instituto de Estudos Medievais 30 
narración que aparece en la obra Nafh al-tīb de al-Maqqarī, además de realizar una breve alusión al romance anónimo que relata el asalto a Coín, su resistencia y la previa victoria que hubo sobre el enemigo cristiano, sorprendentemente ocultada en versiones posteriores del mismo romance.

Se nos dice en la Nubdat al-'asr que, en rabī' II del año 890/1485, "salieron los cristianos con sus huestes en dirección a la parte occidental de al-Andalus; y habiendo tomado como objetivo los castillos de Cártama y Dakwān, diéronles gran embestida hasta que lograron apoderarse de ambos. En el año antes mencionado cayeron también en poder de los cristianos los castillos de Haznalmara y de Xitinin" 76.

Al-Maqqarī en su Nafh al-tīb usa el texto de la Nubḍtat al-'asr y añade datos de extraordinario interés sobre la toma de Dakwān, relatando cómo entraron y murieron 1.000 cristianos enlorigados antes de que cayera esta población en manos castellanas. Las murallas de Dakwān fueron demolidas, pero en su interior se había refugiado gente de Ronda y de la Algarbía, la suficiente como para vencer al enemigo cristiano antes de capitular. Se nos dice que "en el mes de rabī' II del año 890 (abril-mayo de 1485) salió el enemigo con refuerzos hacia la región de Málaga, después de que en el año anterior se hubiera apoderado de algunos castillos, al igual que en esta ocasión sojuzgaría otros tantos, y habiéndose encaminado a Coín demolió sus murallas. No obstante haber allí un contingente de los de la Garbía y de Ronda, entraron en Coín al asalto mil hombre enlorigados, pero Dios Altísimo concedió la victoria sobre ellos a los coineños que los mataron a todos. Pese a ello, pidieron el amán tanto los de Coín, como lo que allí les cogió de Ronda y de la Garbía, y se marcharon"77.

Esta batalla es precisamente la misma que las crónicas castellanas, de manera efímera e imperceptible, relatan la muerte de 30 hidalgos de la casa del Rey, entre los que se hallaron don Tello de Aguilar y don Pedro Ruiz de Alarcón. Un romance anónimo, inserto en el 'Libro de los Cuarenta Cantos', incide en esta insólita victoria de los

\footnotetext{
${ }^{76}$ ANÓNIMO - Nubdat al-'asr, p. 14, trad. in Fragmento de la época sobre noticias de los Reyes Nazaritas o Capitulación de Granada y Emigración de los andaluces a Marruecos. Ed. BUSTANI, Alfredo y trad. QUIRÓS, Carlos. Larache, 1940, p. trad. 16.

${ }^{77}$ AL-MAQQARI - Nafh al-tīb min gusn al-Andalus al-ratīb. Ed. I. 'Abbās, Beirut, 1968, Vol. IV, p. 515. Véase traducción in VELÁZQUEZ BASANTA, Fernando - "La relación histórica sobre las postrimerías del Reino de Granada, según Ahmad al-Maqqarī (siglo XVII)". in DEL MORAL, Celia (ed.) - En el epílogo del Islam andalusí. La Granada del siglo XV. Granada, 2002, pp. 514 y 515.
}

Medievalísta online № 19| Janeiro - Junho 2016 (C) IEM - Instituto de Estudos Medievais 31 
granadinos, hasta el extremo que, debido a ella, "se detuviese Coín gran tiempo sin ser tomado". Lo que tampoco es cierto.

Meses más tarde, tomada la población, los reyes fueron informados que ciertos vecinos de la ciudad de Sevilla y su tierra, que se encontraban ahora en dicha ciudad, "fueron en robar y robaron a ciertos moros de la villa de Coín al tiempo que yo, el Rey, tomé la dicha villa y los dichos moros se iban, estando como estaban por mí asegurados, les tomaron ciertos niños e niñas e mucho dinero e (oro) e plata e joyas e $\operatorname{cosas}^{\text {"78 }}$. No quedaría en entredicho la palabra del monarca, siendo así que, a 19 días de noviembre de 1485, los reyes ordenaron al comendador Gamarra y Cristóbal de Vitoria que fueran a Sevilla y su tierra e hicieren pesquisas e inquisición "para entregar todo a los dichos moros a quien lo tomaron".

Durante el sitio de Málaga, Alí Dordux solicitó el estatuto de mudéjar para la población malagueña y su establecimiento en Coín, pero sólo le fue concedida a él y a su clientela la primera de las condiciones, siendo la villa finalmente repoblada por cristianos viejos. Resulta significativo que la carta real para poblar Coín tenga fecha de finales de marzo de 1488, coincidiendo con el final del plazo que los malagueños tuvieron para pagar su rescate y librarse de la cautividad. Si lo hubieran conseguido, casi con toda seguridad, esta villa hubiera sido repoblada por mudéjares, según indica el profesor Ladero Quesada.

Culminado el asalto, los Reyes Católicos concedieron a esta villa el fuero de Sevilla, siendo éste observado y respetado por el primer corregidor de Málaga Garci Fernández Manrique. Los habitantes fueron despojados de sus tierras y heredades, y éstas repartidas entre cristianos viejos. El último alcaide, llamado en los textos cristianos "Ali Jali", salió de su fortaleza y encontró refugio en el lugar de Guaro ${ }^{79}$, junto a otros muchos vecinos de Coín, allí continuaron cultivando la vega de Río Grande como mudéjares súbditos de Castilla. Otros muchos coineños corrieron peor suerte, cuando no la muerte será el cautiverio, tal es el caso de "Malfat de Deus", presa y cautiva durante

\footnotetext{
${ }^{78}$ AGS, RGS. 148511,24. (Documento sin digitalizar).

${ }^{79}$ AMM, LR vol. I, fol. 174.
} 
la guerra, luego esclava de la mujer de Diego Hurtado de Mendoza y finalmente rescatada en 1498 por seis moros de la morería de Zaragoza ${ }^{80}$.

Aunque quien mejor ilustra las desgracias de la conquista es el cronista Alonso de Palencia (1423-1492), cuando reseña que "en la villa no quedó nada que no se repartieran las tropas, y, arrasadas la mayor parte de las casas, perdió Coín aquel aspecto de belleza que le distinguía entre las otras poblaciones del territorio de Málaga"81.

\section{Conclusiones}

La finalidad última de este trabajo debería explicar el desarrollo urbano vivido en Coín en los últimos siglos de al-Andalus. En otras palabras, cómo una comunidad rural de base agraria pudo evolucionar hasta configurarse en centro urbano durante el periodo nazarí. La respuesta a este fenómeno histórico, generalizado en nuestro contexto geográfico y temporal, creemos, se inserta en el marco teórico que vienen elaborando destacados autores como Pierre Guichard, Pedro Chalmeta, Miquel Barceló y Manuel Acién ${ }^{82}$, entre otros investigadores de reconocido prestigio como Felipe Maíllo, Eduardo Manzano y Antonio Malpica ${ }^{83}$. Son ellos quienes han ido perfilando los rasgos distintivos de la sociedad andalusí, bastante diferentes sin duda de los que presentan las sociedades feudales coetáneas del norte peninsular y el occidente europeo.

Especial relevancia adquiere el esquema de sociedad tributaria propuesto por Samir Amin, el cual ha proporcionado un marco interpretativo adecuado y aceptado prácticamente por la generalidad de autores para describir y entender la formación andalusi ${ }^{84}$, aunque algunos mantengan reservas en cuanto a su validez. En esta línea de

\footnotetext{
${ }^{80}$ GÓMEZ DE VALENZUELA, Manuel - Esclavos en Aragón. Zaragoza, 2014, p. 170.

${ }^{81}$ PALENCIA, Alonso de - Guerra de Granada ... op. cit.

${ }^{82}$ GUICHARD, Pierre - Al-Andalus: estructura antropológica de una sociedad islámica en Occidente. Barcelona, 1976. CHALMETA Pedro - "Le problème de la féodalité hors de l'Europe chrétienne: le cas de l'Espagne musulmane". in II Coloquio Hispano-Tunecino, Madrid, 1973, pp. 91-115. BARCELÓ, Miquel - “QQué arqueología para al-Andalus?”. in MALPICA, A. y QUESADA, T. (eds.) - Los orígenes del feudalismo en el mundo mediterráneo. Granada, 1994, pp. 69-99. ACIÉN ALMANSA, Manuel Entre el feudalismo y el Islam. 'Umar ibn Hafsun en los historiadores, en las fuentes y en la historia. Jaén, 1994.

${ }^{83}$ MAÍLLO SALGADO, Felipe - "De la formación social tributaria ¿y mercantil? andalusí". in Anales de Historia Antigua, Medieval y Moderna. 35-36 (2013), pp. 175-184. MANZANO MORENO, Eduardo Con/quistadores, emires y califas: los Omeyas y la formación de Al-Andalus. Barcelona, 2006. MALPICA CUELLO, Antonio - "La vida urbana en al-Andalus y su papel en la estructura del poblamiento y en la organización social". in Imago Temporis. Medium aevum. IV (2010), pp. 401-420.

${ }^{84}$ AMIN, Samir - Sobre el desarrollo desigual de las formaciones sociales. Barcelona, 1974.
} 
argumentación, como respuesta inmediata a la cuestión planteada, todo hace indicar que el sistema tributario-mercantil impulsó la creación de ciudades y su expansión ${ }^{85}$.

En nuestro ámbito geográfico el poblamiento rural es sin duda de origen andalusí en su gran mayoría, muy diferente al que se constata en las comarcas del Guadalteba y Antequera. Los antiguos centros romanos, situados en los grandes ejes fluviales, fueron poco significativos y no pervivieron mucho más allá, sin que tengamos constancia de reocupación o continuidad poblacional, con la salvedad dicha de Álora, Cártama, Manguarra y cerro del Aljibe. El complejo hiṣnn-qarya se generalizó en al-Andalus ${ }^{86}$, tal vez con salvedades en ciertas regiones, como Mallorca, donde Helena Kirchner distingue redes de alquerías $\sin h u s \underline{u} n^{87}$. En términos generales parece que cada hiṣn contaba aproximadamente entre siete y diez alquerías dependientes en su distrito ${ }^{88}$, no obstante esta afirmación está todavía por constatar en la zona por falta de actuaciones arqueológicas. La forma que adopta Coín en su génesis parece responder a la de un hiṣn fortificado provisto de albacar, al que se le adosa un núcleo poblacional de escasa entidad. En su evolución incorpora recinto amurallado, comprendiendo un perímetro de $4.300 \mathrm{~m}^{2}$ aproximadamente, que pronto quedará desbordado en época bajomedieval por falta de espacio edificable intramuros ${ }^{89}$. El incremento demográfico de esta etapa tendrá reflejo en todas las alquerías de su alfoz, muchas vinculadas a Río Grande, así como también en la ampliación del espacio urbano extramuros y la necesidad de nuevas tierras cultivables adyacentes al núcleo poblacional, lo cual se distingue nítidamente en el pago de Huertas Nuevas y en el arrabal residencial de San Sebastián ${ }^{90}$.

\footnotetext{
${ }^{85}$ MALPICA CUELLO, Antonio - "La vida urbana en al-Andalus...“, pp. 401-420.

${ }^{86}$ GUICHARD, Pierre - Al-Andalus frente a la conquista cristiana. Los musulmanes de Valencia (siglos XI-XIII). Valencia, 2001. ACIÉN ALMANSA, Manuel - "Poblamiento y fortificación en el sur de alAndalus. La formación de un país de hụusūn”". in III Congreso de Arqueología Medieval Española: Oviedo, 27 marzo-1 abril 1989. Oviedo, 1992, pp. 137-150. CRESSIER, Patrice - "Agua, fortificaciones y poblamiento: El aporte de la arqueología a los estudios sobre el Sureste peninsular". in Aragón en la Edad Media. 9 (1991), pp. 403-428.

${ }^{87}$ KIRCHNER, Helena - "Redes de alquerías sin hușūn: una reconsideración a partir de los asentamientos campesinos andalusíes de las islas orientales". in MALPICA, A. (dir) - Castillos y territorio en al-Andalus. Granada, 1998, pp. 450-469.

${ }^{88}$ GLICK, Thomas F. - Paisajes de conquista. Cambio cultural y geográfico en la España medieval. Valência, 2007, p. 41.

${ }^{89}$ Modelos similares en contextos cercanos se documentan en MALPICA CUELLO, Antonio Poblamientos y castillos... op. cit, y del mismo autor "Las villas de la frontera granadina y los asentamientos fortificados de época medieval". in Acta historica et archaeologica mediaevalia. 20-21 (1999-2000), pp. 279-320.

${ }^{90}$ De cara a comprender la evolución y transformación del tejido urbano andalusí remitimos a los trabajos de PAVÓN MALDONADO, Basilio - Tratado de arquitectura hispanomusulmana II. Ciudades y fortalezas. Madrid, 1999. ACIEN ALMANSA, Manuel - "La formación del tejido urbano en al-Andalus".
}

Medievalista online № 19| Janeiro - Junho 2016 @ IEM - Instituto de Estudos Medievais 34 
El crecimiento demográfico es incuestionable en el sur andalusí desde el siglo XII hasta prácticamente su conquista, pero evidentemente debieron incidir otros factores en la formación y evolución de los centros urbanos. Bien conocido es que el Estado suele impulsar la creación de ciudades de nueva planta o el desarrollo de las mismas, a veces para legitimarse; otras por necesidades militares, administrativas o socioeconómicas. En palabras de Felipe Maíllo, “con los conocimientos que hoy poseemos, al-Andalus podría describirse como una formación social tributaria en la que las ciudades primarían sobre el campo". No sin razón, los centros urbanos son imprescindibles para fiscalizar la recaudación tributaria; se convierten además "en centros receptores de renta y desarrollan también la función de mercados"91.

Sin embargo nadie pone en duda hoy que los ingresos del fisco andalusí provenían fundamentalmente de la agricultura, sin despreciar por ello los procedentes del comercio exterior. En este punto, destacaba Pedro Chalmeta que "al-Andalus (en época califal) era una sociedad precapitalista definible como formación social tributaria centralizada, predominantemente agrícola", donde el Estado "perceptor de los impuestos es la entidad superior que organiza, controla y reparte la distribución interior del surplus de la producción" $" 92$.

La necesidad de hacer frente al pago de los impuestos obligaba a los campesinos a entrar en el circuito mercantil y, de ese modo, crear excedente que vender a cambio de moneda, tal pone de relieve Antonio Malpica en diversos trabajos ${ }^{93}$. Siguiendo a este investigador, se hace evidente que esta exigencia contribuyó a desarrollar mercados urbanos y que "la formación de los mercados campesinos son una condición previa a la

in PASSINI, Jean (ed.) - La ciudad medieval: de la casa al tejido urbano. Cuenca, 2001, pp. 11-32. NAVARRO PALAZÓN, Julio y JIMÉNEZ CASTILLO, Pedro - "Evolución del paisaje urbano andalusí. De la medina dispersa a la saturada". in ROLDÁN CASTRO, F. (coord.) - Paisaje y Naturaleza en alAndalus. Granada, 2004, pp. 232-267. ALBA CALZADO, Miguel - "Apuntes sobre el urbanismo y la vivienda de la ciudad islámica de Mérida". in Excavaciones arqueológicas en Mérida 2001. Memoria. 7 (2001), pp. 417-438. GUTIÉRREZ LLORET, Sonia - "Madínat Iyyuh y la destrucción de espacio urbano en la Alta Edad Media". in Castrum 8. Le château et la ville. Espaces et réseaux (VIe-XIIIe siècle). Madrid, 2008, pp. 199-222.

${ }^{91}$ MANZANO MORENO, Eduardo - "Relaciones sociales en sociedades precapitalistas: una crítica al concepto de modo de producción tributario". in Hispania. 58 (1998), pp. 881-914.

92 CHALMETA, Pedro - "Al-Andalus". in Historia de España. Vol. 3, Al-Andalus: musulmanes y cristianos (siglos VIII-XIII), Barcelona, 1996, pp. 8-113. De este mismo autor - "Le problème de la féodalité...", pp. 91-115.

${ }^{93}$ MALPICA CUELLO, Antonio - "La vida urbana en al-Andalus...”, pp. 401-420; idem - "Castillos, alquerías y ciudades en al-Andalus. Un debate partiendo del análisis arqueológico". in MOLINA MOLINA, A. L. y EIROA RODRÍGUEZ, J. A. (coord.) - El castillo medieval en tiempos de Alfonso X el Sabio. Murcia, 2009, pp. 99-120.

Medievalista online $N^{\circ} 19 \mid$ Janeiro - Junho 2016 @ IEM - Instituto de Estudos Medievais 35 
formación de las ciudades, de donde se deduce que el mundo rural estaba convenientemente jerarquizado y existía un excedente apropiable, aunque no de manera directa"94. Desde esta perspectiva es posible explicar cómo muchas "poblaciones pasan de núcleos campesinos a estructuras casi urbanas"95.

En al-Andalus la alquería constituyó la unidad básica de los ingresos fiscales del Estado $^{96}$; y la ciudad "sólo fue posible contando con una estabilización de los órdenes campesinos locales, mercados rurales incluidos" ${ }^{27}$. En el caso de Coín tenemos claro que el policultivo de frutales fundamentaba su riqueza, al menos en época nazarí, pues según Ibn al-Jațịb "la excelencia de sus frutas está por cima de toda ponderación (...).

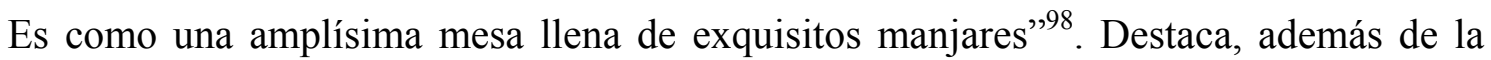
calidad de sus frutas, el rendimiento de sus molinos y la espesura de sus árboles, para seguidamente concluir que "la fama de esta ciudad se pregona por el mundo, como ondea a todo viento un estandarte" 99 . Se infiere de ello que sus productos hortofrutícolas pudieron destinarse a satisfacer la demanda exterior, como bienes de exportación, incluyéndose aquí con toda seguridad aquellas frutas que se desecaban para consumo posterior. Importante fuente de ingresos debió ser la actividad industrial y artesanal basada principalmente en sus muchos molinos de aceite y pan, de los que también habla Ibn al-Jaṭīb en el siglo XIV y los repartimientos castellanos del siglo XV, en gran medida vinculados a los excedentes de cereal de La Jara, y de aceitunas en el curso medio de Río Grande.

El tamaño que alcanzaron sus espacios irrigados y la capacidad de acaparar los productos de su alfoz, ante la inexistencia de otras ciudades próximas, abre la posibilidad de desarrollar mercados de carácter urbano, que, además de colmar la escasez de aquellas comarcas deficitarias de su entorno, pudieron tener buena acogida en otros mercados de largo alcance, aquellos que precisamente le dieron "fama a esta ciudad".

\footnotetext{
${ }^{94}$ Ibidem.

${ }^{95}$ Ibidem.

${ }^{96}$ BARCELÓ, Miquel - "La primerenca organització fiscal d'Al-Andalus segons la 'Cronica del 714" (95/713-138/755)". in Faventia. 1 (1979), pp. 231-261; idem - El sol que salió por Occidente. Valencia, 2010.

${ }^{97}$ BARCELÓ, Miquel - Los Banū Ru'ayn en al-Andalus. Una memoria singular y persistente. Granada, 2004, p. 143.

${ }_{98}$ IBN AL-JAṬ̄̄B - Mi yāār al-ijtiyār ... op. cit., p. 67, trad. p. 138.

${ }^{99}$ Ibidem.
}

Medievalista online $\mathrm{N}^{\circ}$ 19| Janeiro - Junho 2016 @ IEM - Instituto de Estudos Medievais 36 
De las fuentes disponibles, como corolario, se deduce que Coín y Casarabonela fueron los dos grandes centros de abastecimiento y comercio de productos alimenticios en nuestro ámbito geográfico; donde se transforman materias primas y se ponen en circulación manufacturas, donde el fisco nazarí debió obtener sus mayores beneficios y donde se pudieron desarrollar mercados semiurbanos; aunque por otras razones se haya insistido, en más de una ocasión, que "la madina Alura (Álora) pasó a ser cabecera del valle del Guadalhorce, junto a Cártama, a fines del siglo XIV"100.

\section{COMO CITAR ESTE ARTIGO}

\section{Referência electrónica:}

MARMOLEJO CANTOS, Francisco - “Coín en época andalusí, centro administrativo y militar de la Algarbía malagueña”.

Medievalista [Em linha]. No19 (Janeiro - Junho 2016). [Consultado dd.mm.aaaa].

Disponível em

http://www2.fcsh.unl.pt/iem/medievalista/MEDIEVALISTA19/marmolejo1905.html ISSN 1646-740X.

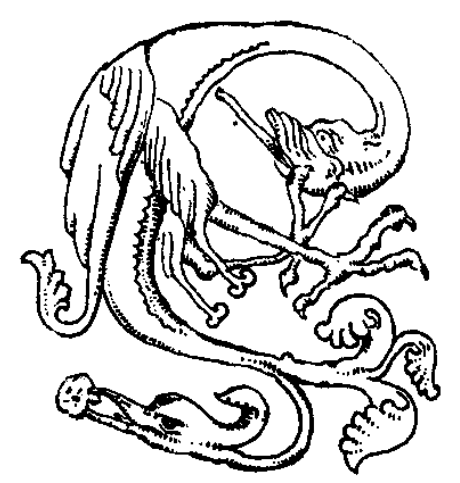

\footnotetext{
${ }^{100}$ Entre los muchos estudios que dan mayor importancia y entidad a Álora y Cártama en periodo nazarí destacamos el trabajo de MARTÍNEZ ENAMORADO, Virgilio - "Una Dar al-Da'wà de los omeyas en las inmediaciones de Bobastro: El castillo de Álora". in Actas del I Congreso de Castellología Ibérica. Palencia, 1998, p. 470.
}

Medievalísta online $N^{\circ} 19 \mid$ Janeiro - Junho 2016 @ IEM - Instituto de Estudos Medievais 37 